\title{
Strengthening Adaptation Planning and Action to Climate-Related Health Impacts in Pacific Islands Countries: Tonga
}

\author{
Annette Bolton ${ }^{1}$, Kamal Khatri ${ }^{1}$, Matthew Ashworth ${ }^{1}$, Sela 'Akolo Fa'u', \\ Sela Ki Folau Fusi², Judy Williamson ${ }^{3} \&$ Reynold Ofanoa ${ }^{2}$ \\ ${ }^{1}$ Institute of Environmental Science and Research Limited (ESR), Christchurch Science Centre, 27 Creyke Road, \\ Christchurch 8041, New Zealand \\ ${ }^{2}$ Department of Environmental Health, Climate Change and Disaster, Ministry of Health, Nuku'alofa, Tongatapu, \\ Tonga \\ ${ }^{3}$ HEW Consultants Limited, Christchurch, New Zealand \\ Correspondence: Annette Bolton, Institute of Environmental Science and Research Limited (ESR), Christchurch \\ Science Centre, 27 Creyke Road, Christchurch 8041, New Zealand. Tel: 64-27-318-3936. E-mail: \\ annette.bolton@esr.cri.nz
}

Received: December 22, 2019 Accepted: January 17, 2020 Online Published: February 15, 2020

doi:10.5539/gjhs.v12n3p55 URL: https://doi.org/10.5539/gjhs.v12n3p55

\begin{abstract}
A natural hazard and climate change vulnerability and adaptation tool was applied in Tonga to identify health and health system-related climate and natural hazards, and to create and prioritize adaptation strategies and opportunities. During a 2-day multi-sectoral workshop, expert stakeholders prioritized the most extreme health-related and health system risks and devised a series of adaptation strategies. A series of health and health system impacts were identified and related to: cyclones/severe storms, increased average and extreme temperatures, flooding (including landslides), drought, wildfire, tsunami, earthquakes and volcanic activity. The main adaptation strategies identified improving drinking water security; development of Government procedures for drought management; linking health and climate data; increasing food security; improvements in urban design; training health workers; increasing evacuation center resilience in villages; increased research into management responses and enforcing and updating the building code. Adaptation to the health and health system impacts explored during the workshop include many outside the scope of the health system. This paper highlights the importance of multi-stakeholder engagement and co-planning to anticipate and plan for natural hazard and climate-related health and health system impacts and; benefits of establishing and using expert knowledge to determine health adaptation connections, build bridges across sectors and prioritize strategies in the absence of climate and health attributable information.
\end{abstract}

Keywords: health, environmental health, climate change, natural hazards, adaptation, Pacific Island Countries, planning, cross-sectoral, vulnerability, Tonga

\section{Introduction}

\subsection{Climate Change and Health in Tonga}

The intergovernmental panel on climate change (IPCC) and the World Health Organization (WHO) have identified small island developing states (SIDS) as some of the most vulnerable to current and future climate-related drivers of risk (Nurse et al., 2014; World Health Organization, 2015a). The risks projected for the 21 st century include increasing air and sea surface temperatures, changing rainfall patterns, storm surges and gale-force winds, sea level rise (SLR), coral bleaching, erosion and tropical and extratropical cyclones (The World Bank 2013; Nurse et al., 2014). These changes to climate can alter health risks associated with: water security and safety; vector borne disease (VBD); food security and safety; zoonoses and respiratory disease (World Health Organization, 2015a). Diffuse impacts are less known but may include disorders of mental/psychosocial health, non-communicable diseases (NCD) and nutrition, food safety and security, health system (as defined by WHO) and population pressures (Skinner et al., 2011; World Health Organization, 2015a; MEIDECC, 2018). There are also likely to be health impacts that are unknown or unpredictable. 
When combined, the impacts of climate change and natural hazards from such events can increase direct physical risk to people and critical health infrastructure and facilities (World Health Organization, 2015a; MEIDECC, 2018).

Global climate model outputs for Tonga indicate that climate change and SLR will have serious effects on the biophysical systems and development sectors of the economy (GEF, 2007). The effects impact fresh water, which is projected to decrease by $10 \%$ overall by 2050 , with a reduction in groundwater recharge by up to $30 \%$. Seasonally dry periods are expected to become even drier and wet seasons wetter, and extreme years when the South Pacific Convergence Zone (SPCZ) moves north and merges with the Intertropical Convergence Zone (ITCZ) are projected to become more frequent with increases in ambient temperature (GEF, 2007; CSIRO, 2015). By 2100, rainfall projections are even lower, on average decreasing by $17.5 \%$ with a $32 \%$ reduction in recharge of the groundwater. In addition to the loss of this resource, SLR can affect groundwater through saltwater intrusion. Flooding associated with climate extremes such as storm surges will also erode land impacting on agricultural production and coastal infrastructure. The 2100 projections show a $1 \mathrm{~m}$ rise in SLR at Tongatapu, part of the southernmost island group and home to the capital and largest city, Nuku'alofa, which accounts for $74 \%$ of the population. Land loss due to SLR equates to $10.3 \mathrm{~km}^{2}$ of land or $37.3 \mathrm{~km}^{2}$ of land associated with storm surges, or a total loss of $14 \%$ of land area of Tongatapu (GEF, 2007; MEIDECC 2018). Tropical cyclones are also projected to increase in severity, although potentially decreasing in frequency (The World Bank, 2017). Previous vulnerability and adaptation assessments in Tonga indicate that key development sectors will likely be affected by climate change. These sectors include water resources, forestry and agriculture, coastal areas and resources, fisheries and human health (GEF, 2007).

In 2015, the WHO identified the health impacts of extreme weather events, water security and safety, food security and safety, VBD and NCD as priority areas for Tonga (World Health Organization, 2015a). Tonga is also experiencing an epidemiological transition (Wahdan 1996) from infectious to NCD which are currently the main cause of morbidity and mortality in Tonga. Due to changing climate NCD are also projected to increase e.g. increased cardiovascular disease and diabetes complications due to increases in heat, air pollution, physical inactivity and dietary changes (Friel et al., 2011; International Diabetes Federation, 2012; Smith et al., 2014; Tonga Health Promotion Forum, 2016; McIver et al., 2016). Together, these pose challenges for the health sector and require sufficient and prioritized adaptation effort across multiple sectors.

\subsection{Tonga Country Profile}

The Kingdom of Tonga (Tonga) is a small developing Polynesian country in the Pacific region with a population of approximately 100,000 people (Tonga Statistics Department, 2016) (Figure 1). Tonga is an island chain, consisting of 176 islands, 52 that are inhabited with a total area of 290 square miles $\left(748 \mathrm{~km}^{2}\right)$ spread over 270,000 square miles in the southern Pacific Ocean. 


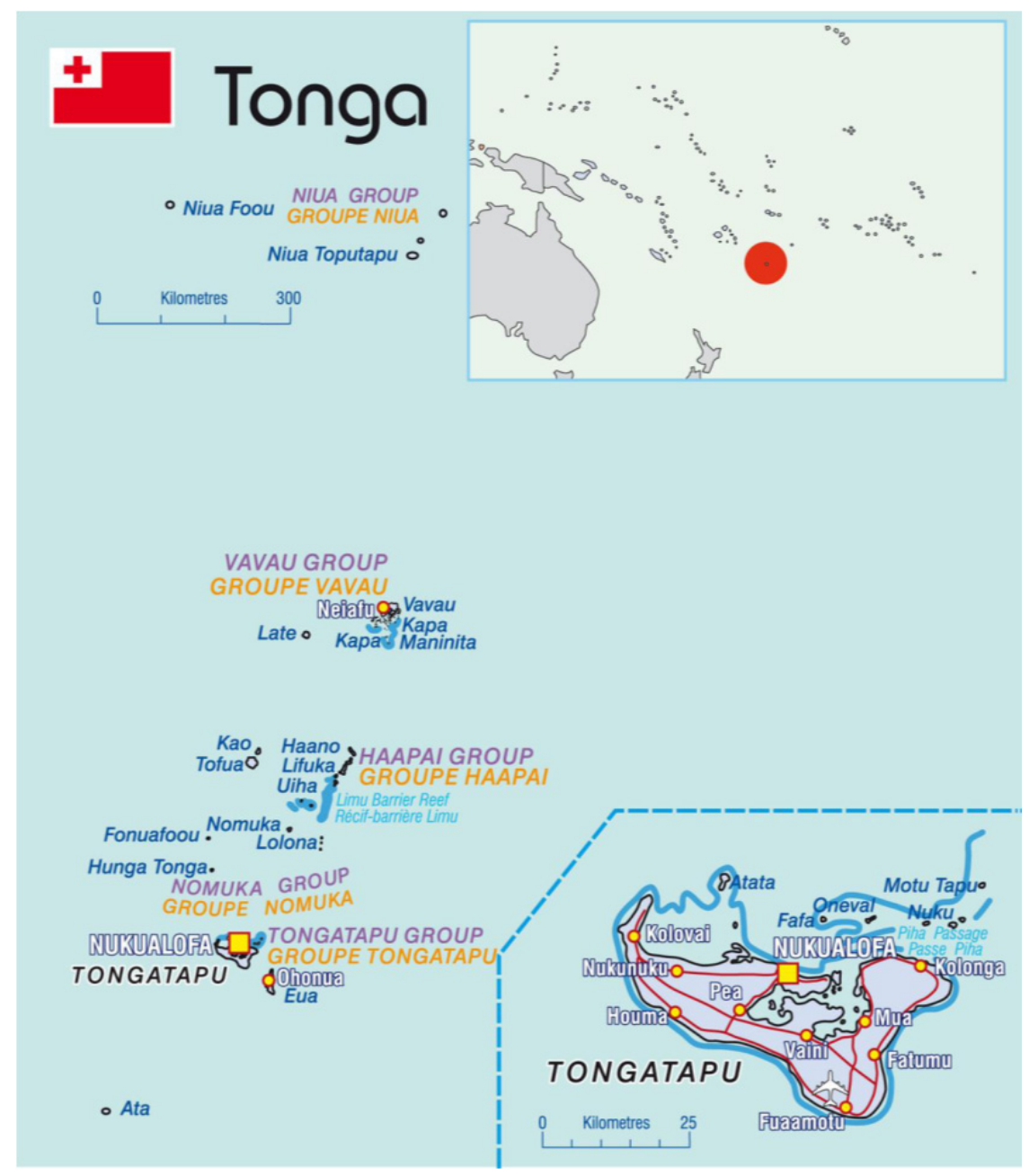

Figure 1. Map of Tonga (Source: GCCA, 2013)

Compared to the rest of the Pacific, Tonga, is generally cooler, due to its southerly latitude $\left(20-21^{\circ} \mathrm{S}\right)$. Depending on the latitude, annual maximum and minimum temperatures range from $28{ }^{\circ} \mathrm{C}$ to $15{ }^{\circ} \mathrm{C}$ respectively (Tonga Meteorological Service - Ministry of Civil Aviation). Rainfall is influenced by the position and strength of the SPCZ, a band of low-level (wind) convergence, cloudiness and precipitation, and the Pacific part of the ITCZ. Tonga's high exposure and susceptibility to natural disasters and climate change has contributed to its ranking as the second most vulnerable country in the world according to The World Risk Report 2018 (Heintze et al., 2018).

\subsection{The Joint National Action Plan Approach}

Planning and adapting for future risks relies on climate projections specific to Tonga but also, critically, on how that information is harnessed for decision making. Vulnerability and adaptation assessments, in-country consultations, and the Pacific joint national action plan for disaster risk management and climate change (JNAP), have provided useful information on the impacts of climate change in general (Tukutau, 2004; USP, 2012; World Health Organization, 2015a; SPC, 2016; MEIDECC, 2018).

The reality for many Pacific island countries (PICs) include pressure to recover from increasing intensities of extreme weather events. Recently, Tropical Cyclone Pam (March 2015), Tropical Cyclone Winston (February 2016) and Tropical Cyclone Gita (February 2018) have caused devastating damage. Historically such hazards are interspersed with natural disasters such as earthquakes, drought and tsunamis. Natural hazards adversely impact health and hinder development and economic opportunities. For example, Tropical Cyclone Evan in Samoa (2012) was estimated to have cost 30\% of GDP estimated at USD \$103.3 million (The World Bank, 2018). Tropical Cyclone Gita impacted 
Tonga at an estimated economic loss of USD \$164 million equivalent to 37.8\% of nominal GDP (Government of Tonga, 2018). However, adaptation opportunities, when delivered in conjunction with other development goals, can generate larger benefits to small islands such as disaster risk reduction and community-based approaches to development (Nurse et al., 2014).

Tonga was one of the first Pacific island countries to develop a joint national action plan for climate change adaptation and disaster risk management. The JNAP is a strategic action framework to address Tonga's climate change and disaster risk management priorities. The first JNAP covered the period 2010-2015 and linked national, regional and international frameworks, policies, plans and agreements e.g. Tonga Climate Change Policy (at a national level), Pacific Disaster Risk Reduction and Disaster Management Framework for Action 2005-2015 (at a regional level), Paris Agreement (at an international level). In 2014 a new Ministry, MEIDECC (Ministry of Meteorology, Energy, Information, Disaster Management, Climate Change and Communications) was created with the mandate to "ensure the protection and proper management of the environment and the promotion of sustainable development". Both the Ministry of Environment and Climate Change (MECC) (within MEIDECC) and the national emergency management office (NEMO) co-developed the JNAP2 which covers the period from 2018 to 2028 (MEIDECC, 2018). A revised climate change policy was also endorsed at the cabinet level in 2016 with a strong resilience theme.

The Ministry of Health $(\mathrm{MoH})$ are one of 13 agencies and sectors that link into the JNAP2 framework, which includes health related impacts from natural hazards and climate change. Other sectors involved in the JNAP2 framework also indirectly influence health. For example, agriculture is threatened by extreme events, SLR and drought, impacting on the availability of fresh and nutritionally dense food. Likewise, transport can decrease air quality, and impact respiratory health. Inadequate infrastructure can mean health centers are inaccessible, particularly during extreme events. These are examples of cross-sectorally linked health pathways and highlights the need for a systems thinking approach (Donald and Taghreed, 2009).

The health sector activities identified in the JNAP2 results framework include vulnerability assessments and priority sector resilience plans (MEIDECC, 2018). Specifically, the need for a systematic evaluation of all health facilities to determine their ability to withstand extreme weather events (e.g. cyclones) and to assess costs for developing secure and sustainable water supplies (roof water collection stored in ground tanks), energy independence (solar power systems) and climate proofing of buildings is mentioned in the chapter on health. A health sector plan, often referred to as a (climate change) and health adaptation action plan (HAAP or CCHAP) was also specified to be developed by 2018 although to date this has not occurred.

In 2017, a request from the Tonga MoH was made to the Institute of Environmental Science and Research, New Zealand, to assist in developing a health adaptation and action plan (HAAP). In July 2018 a team of environmental health scientists $(\mathrm{AB}$ and $\mathrm{KK})$ and a health protection officer (JW) visited the MoH to pilot a vulnerability and adaptation assessment (V\&A) that was led by the MoH. The main objective of the V\&A was intended to provide information for the $\mathrm{MoH}$, in collaboration with other health determining sectors e.g. environment, agriculture, non-Governmental organizations (NGOs), to develop a health action and adaptation plan for climate change, prioritize climate change and adaptation options (actions), and to identify areas requiring further research, information or capacity building. An additional objective was to create a dialogue between other Ministries and sectors to allow and enable engagement of climate change and health related information, and to co-develop solutions from a health perspective, but with the knowledge of key intersecting agencies.

\section{Methodology}

\subsection{A Health Adaptation and Action Plan for Tonga}

To achieve health resilience, a collaborative approach across all health-determining sectors was envisaged. This is important because areas associated with climate related health impacts are not always in the control of the health sector e.g. air pollution. However, the costs from those health determining sectors, without adequate adaptation/intervention will increase the health sector's ability to cope with such impacts. Inclusion of a wide range of sectors and actors that can influence or determine health can support the development and implementation of strategies to minimize the risks associated with climate related impacts on health. This additionally increases awareness of health-related impacts that may not have been given prior attention. Vulnerability assessments must therefore include all stakeholders, as the main benefits of adaptation occur when critical points across sectors of the population are identified and become the focus of adaptation measures (Spickett and Katscherian, 2014).

There are both quantitative and qualitative approaches to collecting climate, hazard and health information to provide 
the evidence required to support and evaluate health resilience plans (e.g. health impact assessment, vulnerability and adaptation (V\&A) assessments, indicators, surveillance data, hospital data etc.). The WHO recommends assessment processes that include inputs from academic experts, to ensure high quality evidence, as well as managerial and operational personnel to ensure relevance to policy and practice. It also states that the process should involve a range of stakeholders and use information from a variety of sources, including health and non-health scientific information, as well as community knowledge and feedback (World Health Organization, 2015b). The involvement of the public and the widest possible range of sectors in all stages of V\&A should provide those with interests the opportunity to engage in the process and act collaboratively to make the best use of possible benefits as well as to minimize potential adverse effects. These recommendations were incorporated into the workshop as described in the following section.

\subsection{Climate Change and Health Vulnerability and Adaptation Assessment: Workshop Process Overview}

The health and action planning tool for Pacific island countries (HAAP-PIC) has been developed as a step-by-step guide to developing a country's Health Adaptation and Action Plan. In conjunction with other available resources (Brown et al., 2014; World Health Organization, 2014; United Nations, 2015; World Health Organization, 2015b) the tool has tried to simplify the process for the initial work required and allow work to continue in country. Unfortunately, poorly resourced and over-committed health staff seldom have the time to read and analyze the vast number of frameworks and policies that exist and provide information required. The HAAP-PIC tool aims to empower individual government health bodies (or equivalent) to develop (and in later years, revise) action plans at their own pace and provides guidance to carrying out the analysis. From a health perspective, the workshop is seen as the first step in a process that will contribute to a co-operative and health-focused approach to adaptation strategies for the sectors associated with natural hazards, climate change, health determining sectors and health sector resilience.

The Tonga workshop was conducted over two days in July 2018. A total of eighteen participants from health $(\mathrm{n}=7)$ and non-health $(n=11)$ sectors took part in the workshop and included public health inspectors, climate change technical officers, meteorological duty forecasters, JNAP2 officers, an education officer, environment/disaster division coordinator, and several project officers representing NGOs (Red Cross, Tonga Community Development Trust, Tonga National Youth Congress, Civil Society Forum of Tonga). The process used in-country expert and stakeholder views to identify the potential impacts that could arise due to climate change and natural hazards in health, health systems, and health-determining sectors.

Individuals were assigned to groups in one of five major areas based on their areas of expertise:

(1) health; environment or ecology e.g. air quality experts, water experts, food

(2) social; economists, lifestyle, housing, workforce, population displacement, psychosocial factors

(3) community services and essential services

(4) sustainable technologies and infrastructure; energy, transport, built environment, sanitation telecommunications, water, waste

(5) "other"; community groups or NGOs.

At the beginning of day one, several presentations were given to the participants that covered climate change projections in Tonga and an update on JNAP II (MEIDECC); current and future impacts of climate change to health $(\mathrm{MoH})$ and an introduction to health adaptation and action plan for climate change and disaster risks for Pacific Island countries (ESR). All the presentations were given in the context of the impact of environmental change on human health and well-being. The timeframe and climate change projections were also discussed. For example, the JNAP2 is designed to adapt to medium to long term changes in climate e.g. 2018-2028 and is a similar timeframe to the Sendai Framework for Disaster Risk Reduction (2015-2030) (United Nations, 2015). Most attendees decided to focus on a shorter timescale (10-20 years) in line with the JNAP2. It is noted that climate change (i.e. long-term changes to weather patterns is used here) but refers to current changes in weather patterns already being experienced in the Pacific, rather than those expected in the next 50-100 years. Following this discussion, each group, was asked to complete a series of tables to identify natural and climate related risks; the health and health system impacts which were split by biophysical, social and service/infrastructure factors and specific vulnerabilities. Vulnerability was described to the participants as the combination of exposure, sensitivity and adaptive capacity:

Vulnerability $=$ Exposure + Sensitivity + Adaptive Capacity

Where Exposure $=$ having no protection from something harmful 
Sensitivity $=$ dependence on the environment e.g. for work, food, shelter and medicine; lack of access to decision making and justice, geographical context, a range of intersecting inequalities including financial, socioeconomic, cultural and gender status

Adaptive capacity = assets (social, physical, financial, natural, human, and cultural) and resources (technological, knowledge and governance) which an individual, household or community may mobilize to build resilience to climate change impacts

Groups were asked to base their risk scores on the evidence available to make decisions where a score of $1=\operatorname{good}$ evidence and 5 = no evidence. Each group was asked to present a summary of their completed work which was opened for discussion.

The second day aimed to assess the potential health and health system impacts by examining and prioritizing the risks. Each of the participants joined in activities designed to consider, assess, and prioritize adaptation responses to the risks identified, to reduce the health impacts and health system for people in Tonga. The three groups were asked to select which of the hazards they would like to promote into the adaptation strategies section. Each group then co-created a table of adaptation strategies that were split into the following five categories below. Each category was explained in a power point presentation and examples were provided:

- Legislative or Regulatory

- Public Education and communication

- Technological or Engineering, Infrastructure Development and Ecosystem Intervention

- Health Intervention and Health Systems

- Research/Information/Surveillance/Monitoring

The adaptation strategies from each group were categorized by theme and displayed on a wall. Dot voting (a facilitation methodology) was used in this process. Each participant was given a selection of dots (red, orange and green). The red dots represented high priority, orange medium and green low. The participants were asked to stick 3 dots next to any adaptation option they considered a priority, and to rate the level of priority by the color of the dot (high, medium, low). The participants were able to use their 3 dots for the same adaptation option, or for any individual option or a mixture.

Finally, feedback form the workshop was collected, and a workshop report was sent to all participants that summarized the workshop process, information collected, key outcomes, knowledge gaps and next steps.

\section{Results}

\subsection{Workshop Participants and Risk Ranking}

The natural hazard or climate change related health risks that participants overall considered the highest risk (extreme) were related to extreme temperature and wildfire. These were followed by risks related to high to extreme events: cyclones/severe storms, increased average temperature, flooding, drought and tsunami. Only volcanic activity was considered to present a low to high risk to health. Those risks were specific to the location and the projected direction of any ash fallout. Using the IPCC 1995 (Watson et al., 1995) for guidance, identified health effects were separated into direct impact (21\%), and indirect (79\%) (Appendix, Table 1).

\subsection{Health and Health System Impacts}

The health and health system related natural hazards and climate change related events identified during day one are summarized in Appendix, Table 1. These events are not new to Tonga but were considered requiring adaptation for the future. Other impacts worth noting are those caused by amplification of El Niño and La Niña events and seasonal changes or shifts in rainfall. The most frequently cited health impact was water security and safety $(n=19)$, followed by food security and safety $(\mathrm{n}=10)$. The most frequently cited health system impacts were capacity of health systems $(\mathrm{n}=7)$, infrastructure $(\mathrm{n}=7)$ and healthcare worker access/ability to cope $(\mathrm{n}=7)$.

\subsection{Vulnerable Groups}

For natural hazard related events, children, persons with disabilities and older people were identified as most vulnerable. In addition, gender, social equity (poorer people) and social conflict was also raised as an issue. People living in brick houses or living/working in high buildings were identified as vulnerable to earthquakes. The entire population of Tonga was considered vulnerable to drought and cyclones. For dengue fever, those living in swampy 
areas were considered at higher risk.

For gradual (e.g. increases in ambient air temperature) climate-related events, children, persons with disabilities and older people were identified as more vulnerable. Areas of high population were considered more vulnerable to changes in temperature, as were poorer communities because of their lower adaptive capacity e.g. increases in food prices due to food security issues. Social conflict was also highlighted as an issue related to SLR, and vulnerable groups were identified related to gender (i.e. females were considered more vulnerable).

For extreme climate-related events, the impact of cyclones identified several vulnerable groups including health care staff and head of households. People with disabilities, older people and young women were identified as vulnerable to landslides, whereas the entire country was vulnerable to flooding.

The extent of vulnerability within the events considered, varied widely and was dependent on the specific health impact and other factors such as socio-economic, health, mental-health status, access to health care services and adaptive capacity.

\subsection{Geographical Vulnerability}

Geographical vulnerabilities can also occur in terms of exposure, sensitivity and adaptive capacity. The areas highlighted in terms of vulnerability show that impacts will not be experienced equally.

Communities in low-lying or in coastal areas, were identified as vulnerable to flooding, SLR, storms and sea-surges. In terms of sensitivity and adaptive capacity, regions with a high proportion of rural or isolated populations were identified at risk from specific hazards, for example landslides, extreme temperatures and drought leading to displacement and potentially relocation.

The main city, Nuku'alofa was identified as vulnerable to some impacts (temperature increase), in addition to additive effects such as urbanization, population density, traffic and air pollution.

Wildfires were more likely to impact on communities with bush allotments, those working in forestry, plantations or that kept (farm) animals. Those living near mosquito breeding habitats such as swampy areas were also more vulnerable to VBD.

\subsection{Health System Vulnerability}

Health system vulnerability may occur from direct physical damage to existing infrastructure. Other vulnerabilities include increases in demand such as the stress on human and resource capacity, lack of medical training, increases in hospital admissions, disruption to critical services and access to health care itself. Outer islands were identified as vulnerable from a health system perspective. Access to health centers, capacity of staff on outer islands and the difficultly of monitoring or support were common issues. Reduced access to essential services and a greater reliance on climatic factors for economic prosperity were identified as the potentially major contributors to vulnerability.

Infrastructure and service vulnerabilities were highlighted in remote areas and islands. Many of the participants mentioned that even basic health services were lacking, such as the availability of medical doctors on some islands.

\subsection{Economic Vulnerability}

Identification of economic vulnerabilities was much weaker compared to other vulnerabilities and probably reflects the lack of economic expertise at the workshop. However, the impacts considered include the increased need to prevent worsening of poverty. Impacts include increases in costs of food, water charges during times of shortage and the need to support communities that depend on the local environment such as farmers or subsidence growers that may suffer from health-related impacts via loss of income.

\subsection{Specific Vulnerabilities}

In addition to the vulnerabilities outlined above, some potential health impacts applied to specific vulnerable groups. People who spend large amounts of time outdoors, either through occupational or lifestyle activities were considered vulnerable to UV exposure and heat-related illnesses.

Other subtler social vulnerability was noted. During discussions related to evacuation centers and the impact on religious beliefs some participants expressed the view that evacuation centers that functioned normally as churches could influence religious beliefs. Other comments suggested that churches were not necessarily hazard proof and that the focus in the future should be on creating evacuation centers for every village.

General social comments also related to crime e.g. theft during natural disasters that resulted in a lack of evacuated 
homes due to fear of burglary. On the other hand, there were serious mental health outcomes observed following natural disasters including homicide and domestic violence due to the stress or inability to deal with the stress (e.g. alcohol abuse).

\subsection{Adaptation Responses}

Participants agreed to focus on extreme hazards. The prioritized adaptation strategies presented in this section are not exhaustive. The strategies represent those from all the sectors who participated, and there is potential for this phase of the tool to be expanded (Appendix Tables 2-7).

Adaptation strategies were identified across five main categories:

- Legislative or regulatory

- Public education and communication

- Technological or engineering, infrastructure, development and ecosystem Intervention

- Health and health system intervention

- Research/information/surveillance/monitoring

The complete list of adaptation strategies (Appendix Table 8) was prioritized by participants (high, med, low) in terms of urgency. The scores (high, med, low) were used to assign weights to each of the options i.e. Each red dot has been given a score of 3 , orange 2 and green 1 . For example, if an adaptation option had 2 red, 1 orange and 1 green dot it would receive a score of $(2 \times 3)+(1 \times 2)+(1 \times 1)=6+2+1=9$ but a total number of dots equaling 4 .

The adaptation strategies with the highest scores (top 30\% cumulative) relate to temperature increase whereas strategies with the second highest scores (next 20\%), relate to drought, temperature and flooding (Table 2).

Table 2. Climate change and health adaptation strategies with the highest scores

\begin{tabular}{ll}
\hline Strategies with the highest scores (top 30\%) & Strategies with the highest scores (top 40-50\%) \\
\hline $\begin{array}{l}\text { Adequate drinking water supply (plus maintenance and security), especially } \\
\text { on the outer islands (increased temperature) }\end{array}$ & $\begin{array}{l}\text { Research - develop Government procedures for } \\
\text { drought management (drought) }\end{array}$ \\
$\begin{array}{l}\text { Linking health and climate data (e.g. hospital admissions) (increased } \\
\text { temperature) }\end{array}$ & $\begin{array}{l}\text { Enforcing current building codes (flooding) } \\
\text { Improve food resilience (engineering, diverting, } \\
\text { storage) (flooding) }\end{array}$ \\
Resilient crops (drought) & $\begin{array}{l}\text { Update building code (ventilation) (increased } \\
\text { temperature) } \\
\text { (increased temperature) }\end{array}$ \\
$\begin{array}{l}\text { Training (personal hygiene, health impacts, water consumption, storage, } \\
\text { management) (drought) }\end{array}$ & $\begin{array}{l}\text { Future-proof reticulated waste water systems } \\
\text { (flooding) }\end{array}$ \\
Ensure every village has an evacuation center flooding) & \\
\hline
\end{tabular}

The results of this V\&A have identified several health and health system related impacts and, importantly, prioritized adaptation activities. The next section discusses the relevant findings from Section 3, in order to develop a health adaptation and action plan.

\section{Discussion}

There is no one size fits all approach to V\&A. In the Pacific, several other climate change vulnerability and adaptation assessments exist. Most are generic e.g. USP (2012) and include some health aspects, whereas other focus on a single issue e.g. SPC (2016). The assessments summarized in Table 1 draw upon several different methodologies. In Kiribati, a whole-of-island (WoI) approach to integrated vulnerability assessment (IVA) was used. This approach forms non-traditional linkages between the health sector and other actors, which enable more informed and efficient 
adaptation planning. Other "types" of V\&A include Community Vulnerability and Adaptation Assessment and Action (CV\&A) which focus on collecting data from the community (elders, men, women, youths and children). Information collected includes experiences in relation to climate variability, change over time, and extreme events, current vulnerability to both climate and non-climate related factors, and on examining current adaptive capacity. Communities are asked to evaluate their perceived vulnerability to future climate related risks, leading to the formulation of adaptation policies to strengthen adaptive capacity. To support decision making, climate modelling and scenario generation and social science can be employed if available.

Table 1 summarizes selected V\&A in Tonga, including those specifically centered on health adaptation. Analysis of these assessments identifies some limitations. There has been no monitoring of the identified health risks or trends. The same risks are being reported within decades of each other, but these are not quantified, so it is not possible to know how those risks have changed over time. Health infrastructure risks do not appear to have been covered well, although it is acknowledged that major assessments must have taken place (i.e. the relocation of the hospital at Ha'apai). The $\mathrm{MoH}$ assessment in 2004, identified socio-economic and demographic risks and recognized the economic costs to health, personal suffering and productivity which had knock-on effects nationally. However, this is an exception rather than the rule. Importantly, to date, except for the JNAP, there appears to have been no climate change and health adaptation discussion at a national and community level. The following sub-sections describe the change and health adaptation suggestions of the workshop.

\subsection{Adequate drinking water supply}

Drinking water supply, maintenance and security was a high adaptation priority. This was also identified by WHO (World Health Organization, 2015a) and SPREP (GEF, 2007). Improving infrastructure development in outer islands and rural areas, including climate change resilience is a policy area of the Government (GEF, 2007) and should be considered from a health lens. Resilience needs to reflect current and future water security sources, safety efforts to increase water supply and quality, and improved water use efficiency. A resilient water supply is strongly influenced by the ability to anticipate and prepare for threats to supply, and this requires bringing together datasets and expertise from a range of sectors. Led by the $\mathrm{MoH}$, Tonga is progressing a national safe and secure drinking water and sanitation programme. Mainstreaming current policies is an important aspect to avoid duplication and create clear lines of governance. A lack of basic infrastructure in remote islands contributes to poor adaptive capacity and even greater vulnerability. Remote islands were viewed as particularly vulnerable to drought and extreme temperatures. Coupled with lack of basic healthcare these communities were perceived as requiring immediate adaptation; for example, ensuring that each village has an evacuation center (see 4.3) and an adequate water supply. In the past, some islands have depleted their drinking water sources and have relied on bottled water being shipped, at an expense and environmental cost (pers. comm. plastic water bottle pollution was noted as one of the environmental costs). In the past, donor agencies had provided portable desalination equipment, but because of their weight there was no suitable marine vessel to take these over to the islands (pers. comm.). Therefore, adaptation needs to consider improving communication and co-ordination between organisations during times of emergency to ensure critical resources reach vulnerable communities in times of need. 
Table 1. Summary of selected vulnerability and adaptation assessments in Tonga. Note that not all of these were specifically focused on health but have been included due to their relevance to health

\begin{tabular}{|c|c|c|c|c|c|c|}
\hline $\begin{array}{l}\text { Vulnerability } r \text { and } \\
\text { Adaptation Assessment } \\
\text { Report }\end{array}$ & $\begin{array}{l}\text { Climate Related Health } \\
\text { Risks Presented }\end{array}$ & $\begin{array}{l}\text { Climate Related Health } \\
\text { System Risks Presented }\end{array}$ & Adaptation Options Presented & Location & Comments & Reference \\
\hline This study & $\begin{array}{l}\text { Water and food safety, } \\
\text { security, access and } \\
\text { capacity }\end{array}$ & $\begin{array}{l}\text { Infrastructure } \\
\text { healthcare } \\
\text { resilience }\end{array}$ & Yes & National & $\begin{array}{l}\text { Health risks are } \\
\text { those prioritized }\end{array}$ & This paper \\
\hline $\begin{array}{l}\text { Climate change } \\
\text { vulnerability assessments } \\
\text { for communities in six } \\
\text { Pacific Island countries: } \\
\text { Fiji, Kiribati, Samoa, } \\
\text { Solomon Islands, Tonga } \\
\text { and Vanuatu (2016) }\end{array}$ & 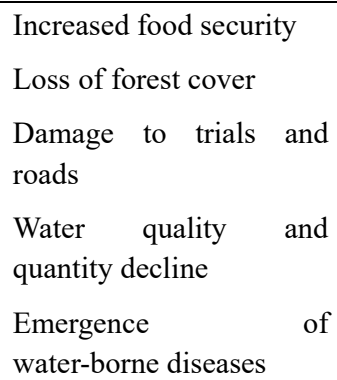 & No & Yes & $\begin{array}{l}\text { Houma village } \\
\text { ('Eua) } \\
\text { Tefisi village } \\
\text { (Vava'u) } \\
\text { Kolonga village } \\
\text { (Tongatapu) }\end{array}$ & $\begin{array}{l}\text { Not specifically } \\
\text { health focused but } \\
\text { includes some } \\
\text { health-related } \\
\text { areas. }\end{array}$ & SPC 2016a \\
\hline $\begin{array}{lrr}\text { Results of Land } & \text { Cover } \\
\text { Type Mapping } & \text { and } \\
\text { Coconut Resource } & \text { Field } \\
\text { Inventory Using } & \text { World } \\
\text { View-2 Image } & \text { Data, } \\
\text { Tonga Vava'u Island } \\
(2016)\end{array}$ & $\begin{array}{l}\text { Coconut } \quad \text { Resource } \\
\text { Inventory }\end{array}$ & & Limited & Vava'u Island & & SPC 2016 b \\
\hline $\begin{array}{l}\text { Enhanced Climate Change } \\
\text { Resilience of Food } \\
\text { Production Systems for } \\
\text { selected PICTs Tonga } \\
\text { Vulnerability Analysis } \\
\text { Report }\end{array}$ & Food security & & Yes - as part of JNAP & $\begin{array}{l}\text { Kolonga } \\
\text { Village, } \\
\text { Tongatapu } \\
\text { Houma village, } \\
\text { 'Eua } \\
\text { Tefisi village, } \\
\text { Vava'u }\end{array}$ & & $\begin{array}{ll}\text { US } & \text { Aid } \\
2017 & \end{array}$ \\
\hline $\begin{array}{l}\text { Rapid Vulnerability and } \\
\text { Adaptation Assessments } \\
\text { of six Communities in } \\
\text { Tongatapu, Ha'apai, and }\end{array}$ & $\begin{array}{l}\text { Water supply and security } \\
\text { Water quality } \\
\text { Water-borne and vector }\end{array}$ & & $\begin{array}{l}\text { Areas were prioritized but no } \\
\text { adaptation. Recommendations to } \\
\text { select pilot sites for further work. }\end{array}$ & $\begin{array}{l}\text { Popua Village } \\
\text { Sopu } \\
\text { Tatakamotonga }\end{array}$ & & USP 2012 \\
\hline
\end{tabular}




\begin{tabular}{|c|c|c|c|c|c|c|}
\hline \multirow[t]{7}{*}{ Vava'u, Tonga (2012) } & \multicolumn{3}{|l|}{ borne diseases } & \multicolumn{3}{|l|}{ Village } \\
\hline & Sanitation & & & Ha'afeva Island & & \\
\hline & Food security & & & Tu'anekivale & & \\
\hline & Energy & & & Village & & \\
\hline & Disaster risk management & & & Ovaka Village & & \\
\hline & Housing & & & & & \\
\hline & $\begin{array}{l}\text { Determinants of health } \\
\text { (income per household) } \\
\text { and source of income. }\end{array}$ & & & & & \\
\hline $\begin{array}{l}\text { Joint National Action Plan } \\
2 \text { (2018) }\end{array}$ & $\begin{array}{l}\text { Vector-borne disease } \\
\text { Drinking water security } \\
\text { (drought) } \\
\text { Drinking water quality } \\
\text { (saltwater intrusion/Sea } \\
\text { level rise) }\end{array}$ & $\begin{array}{l}\text { Health facility vulnerability } \\
\text { to climate change and } \\
\text { disaster impacts (extreme } \\
\text { weather events) }\end{array}$ & $\begin{array}{l}\text { Some adaptation work undertaken: } \\
\text { installation of water tanks in } \\
\text { schools, churches and } \\
\text { communities, climate proofing of } \\
\text { schools and community halls, } \\
\text { evacuation roads, relocation of } \\
\text { hospital in Ha'apai. } \\
\text { Includes sector resilience plan for } \\
\text { health, water resources. }\end{array}$ & National & & $\begin{array}{l}\text { MEIDECC } \\
2018\end{array}$ \\
\hline $\begin{array}{l}\text { Human health and climate } \\
\text { change in Pacific island } \\
\text { countries (2015) }\end{array}$ & $\begin{array}{l}\text { Water safety/security and } \\
\text { diarrheal diseases } \\
\text { Food safety/security } \\
\text { Vector borne diseases } \\
\text { (esp. dengue) } \\
\text { Nutrition and its links } \\
\text { with NCDs } \\
\text { Injuries, deaths from } \\
\text { extreme weather vents } \\
\text { (tropical storms, floods } \\
\text { and other climate-related } \\
\text { disasters }\end{array}$ & $\begin{array}{l}\text { Damage to infrastructure } \\
\text { from extreme weather vents } \\
\text { (tropical storms, floods and } \\
\text { other climate-related } \\
\text { disasters) }\end{array}$ & $\begin{array}{l}\text { Adaptation options focused on } \\
\text { water and food safety and security. }\end{array}$ & National & & $\begin{array}{l}\text { WHO } \\
2015 b\end{array}$ \\
\hline $\begin{array}{l}\text { Climate change project } \\
(2004)\end{array}$ & $\begin{array}{l}\text { Flooding (injuries) } \\
\text { Water borne disease } \\
\text { Food borne disease }\end{array}$ & $\begin{array}{l}\text { Loss or damage to health } \\
\text { infrastructure (SLR, } \\
\text { extreme weather events) }\end{array}$ & Yes & National & $\begin{array}{l}\text { This V\&A was } \\
\text { MOH led. }\end{array}$ & $\begin{array}{l}\text { Tukutau } \\
2004\end{array}$ \\
\hline
\end{tabular}


Malnutrition (loss of food Loss of determinants of

resources)

health (housing/resources)

Vector borne disease

Increased stress

healthcare system

Water shortage

Skin infections

Respiratory disease

including allergic

disorders (air pollution)

and influenzas (following

cyclonic activity)

Socio-economic and

demographic dislocation

(overcrowding, decline in

socio-economic

development

psychological disorders) 


\subsection{Linking Health and Meteorological Data}

Linking health and meteorological data (e.g. hospital admissions) and therefore historical changes was the second highest adaptation priority identified. Ascription of disease to meteorological conditions is challenging but can be used to provide evidence based on detection and attribution (Ebi KL, 2017). This allows health departments to prioritize the current, and plan for future climate change-related health burdens and derive evidence-based policies (Baicker and Chandra, 2017). This also supports actions to mitigate greenhouse gas emissions.

However, some challenges were identified. First, in order to gather appropriate correlations, historical data is required. This may or may not exist as some health records are manually recorded and would require large amounts of labor to digitize. To acquire the health data that is not already collected, digital health information systems need to be in place and capable staff (e.g. health and data analysts) will be needed or need to be trained. It is noted that SPC via the Fiji National University and ESRs Healthy Pacific Environments programme have developed training courses to support some of those needs.

The health sector needs to monitor the developing impacts of climate change, the effects on the population and the level of preparedness of its and other sector services, and communities. The relationship between health and climate can also be used from a modelling perspective to provide projections spatially and various climate scenarios. This information can be used to inform stakeholders where and what adaptation mechanisms will need to be resourced in the medium to long term.

Many countries are adopting centralized approaches to collecting climate, environmental, epidemiological and health related data e.g. The US Centre for Disease Control and the European E3 network (National Center for Environmental Health 2019; European Environment and Epidemiology Network E3 Geoportal 2005-2019). Coordination and communication of climate and natural hazard related risks and opportunities could also be improved via the creation of an information platform that can be used across multiple sectors and countries.

The Environmental Public Health Tracking (EPHT) system under development in Tonga will bring together data sets critical to supporting adaptation planning. The EPHT system will link the impacts of environmental hazards, meteorological events and vector incursion, with community and national-level health outcomes. Data to support EPHT is drawn from several stakeholders which enables the development of a current, quality-assured and nationally coherent dataset, that can derive environmental health intelligence for adaptation planning. This avoids working in silos, holding back critical information and duplication. It also improves decision making, increases transparency across sectors and can be used to develop health early warning systems.

\subsection{Planning Ahead: Evacuation Centers, Urban Design and Building Resilience}

Provision of adequate evacuation centers and improving and enforcing the building code would lead to improved health outcomes, and particularly so in the event of natural disasters. Procedures to deal with drought such as water management, training, understanding the health impacts was another high priority area that is likely to be led outside of the health sector.

Many health adaptation strategies were cross-cutting (e.g. resilient crops, improving and enforcing building codes, creating more shade). Co-ordination across sectors is already included as part of the JNAP2. The health sector component could be strengthened by a health national adaptation and action plan that would support cross agency national planning. For example, resilient crops and improving food resilience are areas that should be led by agricultural departments but would also yield co-benefits to health. Integrated planning to create more shade (with edible plants) was another adaptation option that ideally would be led by urban and rural planners but alleviate heat impacts. Additionally, urban planners can support physical activity by creating spaces that encourage opportunities for light to moderate exercise and in turn support NCD initiatives. Community health is reliant on resilient infrastructure and services such as clean water, reliable energy, transport, communication, medical and other services. Strengthening those systems will form an important component of adaptation plans. Currently, cardiovascular and chronic respiratory diseases, diabetes and cancers account for more than 80 percent of deaths. Although the implementation of priority interventions for NCDs can prove challenging and have been considered the main obstacle in Pacific island countries and territories (Magnusson and Patterson, 2015; World Health Organization, 2015a), Tonga are already heading in the right direction by the provision of more recreational areas that encourage walking and cycling (pers. comm.).

\subsection{Training and Research}

Education (and communication) has a key role, including capacity building across the health sector, to improve preparedness of the health impacts currently and to come. The development of a research agenda (e.g. a climate change research action plan, further research into indirect impacts of climate change on non-communicable 
diseases, successful implementation of adaptation in other PICs), to address knowledge gaps and monitor current and future health burdens is needed.

Alongside implementing adaptation strategies there needs to be an awareness of the current health care system. For example, previous work by Smith et al. (Smith and R. Sauerborn, 2014) identified issues with the number of doctors and medical specialists, the availability of medicine and aged medical equipment in the country. These issues are exacerbated in the outer islands that are low in infrastructure and staff capacity and have limited access to healthcare.

In terms of research gaps, updated V\&A should include social care, gender equity and more information on the role of community, voluntary sector and NGO's. Aged groups were identified as vulnerable to a wide range of potential climate or natural hazard impacts, particularly temperature, cyclones and volcanic activity. Pre-existing medical conditions can also increase vulnerability to a range of health impacts (e.g. diabetes and asthma).

\subsection{Resourcing}

An unintended outcome of Tonga's JNAP process was the need for the MoH to develop its own climate change and health adaptation plan, which currently is not able to be resourced by the green climate fund (GCF). The WHO have recognized that the GCF has not typically funded health related adaptation projects in the Pacific, and it is noted that there are now efforts to understand the funding barriers for health-related projects and to address this need. It was also observed that there are several NGO's and civil society organizations working in this space who are critical to engage with.

\subsection{Key Findings}

The main objective of this V\&A was to provide information for the $\mathrm{MoH}$, in collaboration with other health determining sectors to develop a health action and adaptation plan for climate change, prioritize climate change and adaptation options (actions), and to identify areas requiring further research, information or capacity building. An additional objective was to create a dialogue between other Ministries and sectors to allow and enable engagement of climate change and health related information, and to co-develop solutions from a health perspective, but with the knowledge of key intersecting agencies.

The main health and health system impacts (rated high to extreme) identified were from the events: cyclones/severe storms, increased average and extreme temperatures, flooding (including landslides), drought, wildfire, tsunami, earthquakes and volcanic activity. However, the health impacts were not necessarily correlated. For example, wildfire was identified as an extreme natural hazard, but when all hazards were translated into health risks water and food safety, security and access; capacity; infrastructure and healthcare worker resilience were the most prioritized and relate to multiple climate and natural hazards. The main adaptation strategies included improving drinking water security by for example improving water management, development of Government procedures for drought management; linking health and climate data; increasing food security by research and use of more resilient crops; improvements in urban design; training health workers; increasing evacuation center resilience in villages; increased research into management responses and enforcing and updating regulation.

Pacific island nations have a unique advantage in their small size. In Tonga, the JNAP2 process has formalized inter-agency collaboration. Within Ministries, NGOs and communities exist strong informal networks. In the workshops open and frank discussions and a collegial approach to problem solving were observed, knowledge sharing and high degree of social capital. There is also a shared sense of urgency with climate change mitigation and adaptation shared across these networks, which was expressed by a need to continue the adaptation and action process into a costing and implementation stage.

\subsection{Limitations}

This paper forms the basis of a Health Adaptation and Action Plan for climate change and disaster risks (HAAP) for Tonga. There are however a few essential steps and limitations that need to be considered. The following list refers to identified limitations and participant feedback from the workshop.

- The approach used here was led and initiated by the $\mathrm{MoH}$ with a diverse range of participants from health and non-health sectors taking part in the workshop. It is acknowledged that adequate representation from all relevant sectors may not have occurred.

- The current management practice section was not completed on day 1 of the workshop due to time constraints. Although some of the adaptation options provided allude to management issues, it would be advantageous to cover this section in more detail to identify any current risks, priorities or gaps. This also agrees with the feedback from the workshop that suggest it is taken place over 3 days rather than 2 with 
1 st day organised around key sectors presenting on areas within climate change and disaster risks that they are working on.

- To consolidate all the inputs from relevant stakeholders, a 1-day consultation workshop of a draft HAAP will ensure a plan that is agreed at a national level.

- To draft cost estimates for adaptation options an economist with good knowledge of climate change will need to be engaged

- The HAAP-Tonga needs to be the health sector's plan (i.e. MoH) to meet JNAP2 requirements. It is anticipated that through the Department of Climate Change (MEIDECC) the MoH will be well placed to facilitate the financing requirements identified from various climate change funding mechanisms. This can be achieved through Green Climate Fund, Global Environment Facility (GEF) and other development partners and donors.

- The health sector needs to monitor the developing impacts of climate change, the effects on the population and the level of preparedness of services and communities.

- Further support should be given to embed climate change into local thinking and decision making, enhanced by a sound platform of information from nationally collated information and intelligence.

- Coordination and communication of climate and natural hazard related risks and opportunities could be improved.

- Future reports should include social care, particularly vulnerable populations and more information on the role of small providers, community, voluntary sector and NGO's. It was observed that there are several non-governmental organisations and civil society organisations (CSOs) working in this space who are critical to engage with.

- Attribution of disease, meteorology and climate change was considered one of the most important adaptation options, however to acquire these, health information systems need to be in place and staff considerations (e.g. health and data analysts) will need to be provided.

- The provision above can also be used to develop health early warning systems.

- Create a platform from which to centralise all the health-related data (e.g. information portal).

- The health sector should also consider its contribution of heat-trapping gases e.g. $\mathrm{CO}_{2}$ and prepare in terms of mitigation.

- Compare previous health impacts and updated health impacts as a baseline data for health.

- Integrate previous research into the adaptation plan

- Further research into indirect impacts of climate change on non-communicable diseases need to be collated for the Pacific region and for Tonga.

- Sharing useful learnings from this workshop should similar workshops be carried out in other Pacific island countries.

- A pre-workshop for key health related sectors in-country to ensure enough time, planning and buy-in is made. This will allow further strengthening of ties with $\mathrm{MoH}$ and facilitate a stronger engagement and participation during the actual workshop.

\section{Conclusions}

Testing of a climate and natural hazard health V\&A tool, across multiple stakeholders led by the MoH, identified several key health and health system impacts, and adaptation opportunities in Tonga.

A key insight is the need for multiple stakeholder co-development, including involvement in V\&A assessments. This increases awareness of health in other policies and should lead to less exclusion of the health sector in adaptation planning and avoid critical actions to protect population health (World Health Organization, 2014). This will be aided by the development of functional and regionally interoperable environmental health, meteorological, and climate data-management and interpretation system. Such systems will be critical to supporting decision-making by providing quantitative/empirical evidence of where greatest vulnerabilities lie; support rapid dissemination and sharing of intelligence to support 'incident-response' activities and maintain effective monitoring and evaluation of health actions.

Another insight is that many health opportunities lie outside of the health sector. With that comes a potential 
opportunity cost that would unequally fall on the health sector. On the flip side, opportunities that lie outside of the health care sector offer many co-benefits, such as improving food and water security, reducing other health burdens (e.g. NCDs) and encouraging personal and community resilience.

\section{Acknowledgements}

The development of the HAAP-PIC tool and workshop was supported by the strategic science investment fund provided by the Institute of Environmental Science and Research Ltd (ESR). The authors acknowledge the support from the Tonga Ministry of Health $(\mathrm{MoH})$ in particular Dr. Reynold Ofanoa, Sela Ki Folau Fusi, Sela Akolo Fa'u', Meleane Vainikolo $(\mathrm{MoH})$, coordinating role of Matthew Ashworth (ESR), the contribution from presenters (MEIDEC and $\mathrm{MoH}$ ) and all the sectors who kindly donated their time and expertise to participate in the workshop.

\section{Competing Interests Statement}

The authors declare that there are no competing or potential conflicts of interest.

\section{References}

ADB (Asian Development Bank). (2013). The economics of climate change in the Pacific. Asian Development Bank, Manila, Philippines. Retrieved December 20, 2019, from https:/www.adb.org/sites/default/files/publication/31136/economics-climate-change-pacific.pdf

Baicker, K., \& Chandra, A. (2017). Evidence-based health policy. New England Journal of Medicine, 377, 2413-2415. https://doi.org /10.1056/NEJMp1709816

Brown, H., Spickett, J., \& Katscherian, D. (2014). A health impact assessment framework for assessing vulnerability and adaptation planning for climate change. International Journal of Environmental Research and Public Health, 11, 12896-12914. https://doi.org /10.3390/ijerph111212896

CSIRO, Australian Bureau of Meteorology and SPREP. (2015). Climate in the pacific: A regional summary of new science and management tools, pacific-Australia climate change science and adaptation planning program summary report. Melbourne, Australia: Commonwealth Scientific and Industrial Research Organisation. $\begin{array}{llll}\text { Retrieved July } & 2, & 2019, & \text { from }\end{array}$ https://www.pacificclimatechangescience.org/wp-content/uploads/2013/06/Climate-in-the-Pacific-summary -48pp_WEB.pdf

Donald, D. S., \& Taghreed, A., (2009). Alliance for Health Policy and Systems Research and World Health Organization. Systems thinking for health systems strengthening. Alliance for Health Policy and Systems Research and the World Health Organization. Retrieved July 2, 2019, from https:/www.who.int/alliance-hpsr/resources/9789241563895/en/

Ebi, K. L., Ogden, O. N., Semenza, J. C., \& Woodward, A, (2017). Detecting and attributing health burdens to climate change. Environmental Health Perspectives, 125(8). https://doi.org/10.1289/EHP1509

ECDC European Centre for Disease Prevention and Control Network 2005-2019. (2019). E3 geoportal, European environment and epidemiology network. European Environment and Epidemiology Network. Retrieved July 2, 2019, from https://e3geoportal.ecdc.europa.eu/sitepages/home.aspx

Friel, S., Bowen, K., Campbell-Lend rum, D., Frumkin, H., McMichael, A. J., \& Rasanathan, K. (2011). Climate Change, Noncommunicable Diseases, and Development: The Relationships and Common Policy Opportunities. Annual Review of Public Health, 32, 133-147. https://doi.org/10.1146/annurev-publhealth-071910-140612

GEF, UNDP, SPREP, Government of Tonga, (2007). Pacific adaptation to climate change: Kingdom of Tonga. Report of in-country consultations. Accessed 2/5/2019. URL: GEF, UNDP, SPREP, Government of Tonga Government of Samoa and World Bank. (2018). Samoa post-disaster needs assessment: Cyclone Evan 2012. $\begin{array}{llll}\text { Retrieved } \quad \text { May } & 2, & \text { 2019, from }\end{array}$ http://www.gfdrr.org/sites/gfdrr/files/SAMOA_PDNA_Cyclone_Evan_2012.pdf

Government of Tonga. (2018). Post disaster rapid assessment. Tropical cyclone Gita February 12, 2018. $\begin{array}{llll}\text { Retrieved } \quad \text { May } & 2019, & \text { from }\end{array}$ https:/www.gfdrr.org/sites/default/files/publication/tonga-pdna-tc-gita-2018.pdf

Heintze, H.-J., Kirch, L., Küppers, B., Mann, H., Mischo, F., Mucke, P. et al. (2018). World risk report 2018. Bündnis Entwicklung Hilft and Ruhr University Bochum - Institute for International Law of Peace and Armed Conflict (IFHV), Bündnis Entwicklung Hilft. 
International Diabetes Federation. (2012). Diabetes and Climate Change Report. Retrieved October 1, 2019, from https://ncdalliance.org/sites/default/files/rfiles/IDF\%20Diabetes\%20and\%20Climate\%20Change\%20Policy $\% 20$ Report.pdf

Magnusson, R. S., \& Patterson, D. (2015). How Can We Strengthen Governance of Non-communicable Diseases in Pacific Island Countries and Territories? Asia \& the Pacific Policy Studies, 2, 293-309. https://doi.org/10.1002/app5.84

McIver, L., Kim, R., Woodward, A., Hales, S., Spickett, J., Katscherian, D., Hashizume, M., ... Ebi, K. L. (2016). Health Impacts of Climate Change in Pacific Island Countries: A Regional Assessment of Vulnerabilities and Adaptation Priorities. Environmental Health Perspectives, 124, 1707-1714. https://doi.org/10.1289/ehp.1509756

MEIDECC, (2018). Joint national action plan 2 on climate change and disaster risk management (JNAP 2) 2018-2028. Tonga: Department of Climate Change, Ministry of Meteorology, Energy, Information, Disaster Management, Environment, Climate Change and Communications.

Nurse, L. A., McLean, R. F., Agard, J., Briguglio, L. P., Duvat-Magnan, V., Pelesikoti, N., et al. (2014). Small islands. Climate change 2014: Impacts, adaptation, and vulnerability. Part b: Regional aspects. Cambridge, United Kingdom and New York, NY, USA.

Skinner, M. P., Brewer, T. D., Johnstone, R., Fleming, L. E., \& Lewis, R. J. (2011). Ciguatera Fish Poisoning in the Pacific Islands (1998 to 2008). PLoS neglected tropical diseases, 5, e1416. https://doi.org/10.1371/journal.pntd.0001416

Smith, G., Carter, G., Xiaojing, M., Tararia, A., Tupou, E., \& Weitao, X. (2014). The development needs of Pacific island countries. UNDP. Retrieved July 2, 2019, from https://www.undp.org/content/dam/china/docs/Publications/Pacific\%20Research\%20Report\%208\%200ct\% 20ZC.pdf

Smith, K. R., Woodward, A., Campbell-Lendrum, D., Chadee, D. D., Honda, Y., Liu, Q., ... Sauerborn, R. (2014). Human health: impacts, adaptation, and co-benefits. In: Field, C.B., Barros, V.R., Dokken, D.J., Mach, K.J., Mastrandrea, M.D., Bilir, T.E., Chatterjee, M., Ebi, K.L., Estrada, Y.O., Genova, R.C., Girma, B., Kissel, E.S., Levy, A.N., MacCracken, S., Mastrandrea, P.R., White, L.L. (Eds.), Climate Change 2014: Impacts, Adaptation, and Vulnerability. Part A: Global and Sectoral Aspects. Contribution of Working Group II to the Fifth Assessment Report of the Intergovernmental Panel on Climate Change. Cambridge University Press, Cambridge, United Kingdom and New York, NY, USA, 709-754.

SPC. (2016). Climate change vulnerability assessments for communities in six Pacific Island countries: Fiji, Kiribati, Samoa, Solomon Islands, Tonga and Vanuatu. Pacific Community and United States Agency for International development, Suva, Fiji. Retrieved July 2, 2019, from http://ccprojects.gsd.spc.int/wp-content/uploads/2016/04/Web_whole_Climate_change_Vulnerability_Asses sments.compressed.pdf

Spickett, J. T., \& Katscherian, D. (2014). Health impacts of climate change in the Solomon Islands: an assessment and adaptation action plan. Global Journal of Health Sciences, 6, 261-273. https://doi.org/10.5539/gjhs.v6n5p261

The World Bank. (2017). Climate change and disaster management. Pacific Possible Background Paper No. 6. Washington, DC 20433: International Bank for Reconstruction and Development/The World Bank, 136. Retrieved July 2, 2019, from http://documents.worldbank.org/curated/en/655081503691935252/pdf/119111-WP-PUBLIC-p154324-ppCl imatechangebackgroundfinal.pdf

Tonga Health Promotion Forum (TongaHealth). (2016). National strategy for prevention and control of non-communicable diseases 2015-2020. Retrieved July 2, 2019, from https://ffat.gov.au/about-us/publications/Documents/tonga-national-non-communicable-disease-strategy-20 15-20.pdf

Tonga Meteorological Service - Ministry of Civil Aviation. Climate summary of Tonga. Retrieved July 2, 2019, from http://www.met.gov.to/index_files/climate_summary_tonga.pdf

Tonga Statistics Department. (2016). Tonga population census 2016. Nukualofa: Tonga Statistics Department. Retrieved July 2, 2019, from https://tonga.prism.spc.int/ 
Tukutau, F. (2004). Climate Change Project - 2004. Vulnerability Assessment of Climate Impacts on Health, Tonga. Ministry of Health, Tonga.

United Nations. (2015). Sendai framework for disaster risk reduction 2015 - 2030. United Nations Office for Disaster Risk Reduction (UNDRR), pp. 32. Retrieved May 2, 2019, from https://www.unisdr.org/we/inform/publications/43291

USP. (2012). Rapid Vulnerability and Adaptation Assessments of six Communities in Tongatapu, Ha'apai, and Vava'u, Tonga. September and October 2012. USP Pacific Centre for Environment and Sustainable Development, 1-36.

Watson, R. T., Zinyowera, M. C., \& Moss, R. H. (1995). Impacts, adaptations and mitigation of climate change: Scientific-technical analyses. Contribution of working group ii to the second assessment report of the intergovernmental panel on climate change. Cambridge: Cambridge University Press.

World Health Organization. (2014). WHO guidance to protect health from climate change through health adaptation planning. Accessed 2/7/2019. URL: https://apps.who.int/iris/bitstream/handle/10665/137383/9789241508001_eng.pdf?sequence=1

World Health Organization. (2015a). Human health and climate change in Pacific island countries. Retrieved July 2, 2019, from https://iris.wpro.who.int/bitstream/handle/10665.1/12399/9789290617303_eng.pdf

World Health Organization. (2015b). Operational framework for building climate resilient health systems. Retrieved July 2, 2019, from https://www.who.int/globalchange/publications/building-climate-resilient-health-systems/en/

\section{Appendix}

Table 1. Summary of the health and health system impacts related to natural hazards and climate related risks identified in the workshop. Health impacts with asterisks are those identified as indirect, as defined in IPCC, 1995

\begin{tabular}{|c|c|c|c|c|}
\hline $\begin{array}{l}\text { Natural hazard } \\
\text { or climate related } \\
\text { event }\end{array}$ & Health Impact & Health System Impact & $\begin{array}{l}\text { Risk } \\
\text { score }\end{array}$ & $\begin{array}{l}\text { Evidence } \\
(1-5)\end{array}$ \\
\hline $\begin{array}{l}\text { cyclones/severe } \\
\text { storms (includes } \\
\text { sea-level rise) }\end{array}$ & $\begin{array}{ll}\text { - } & \begin{array}{l}\text { Food safety and } \\
\text { security } \\
\text { nutrition) }\end{array} \\
\text { - } & \text { Water contamination } \\
\text { - } & \text { Water security (SLR) } \\
\text { - } & \text { Vector-borne disease } \\
\text { - } & \text { Decreased wellbeing } \\
\text { - } & \text { Increased risk from } \\
\text { - } & \text { VBD/vermin } \\
\text { - } & \text { Water pollution } \\
\text { - } & \text { Mental health } \\
\text { - } & \text { All water borne } \\
\text { diseases } & \text { Death }\end{array}$ & $\begin{array}{l}\text { - Access to health care and } \\
\text { emergency services }\end{array}$ & $\begin{array}{l}\text { High to } \\
\text { Extreme }\end{array}$ & $3-5$ \\
\hline $\begin{array}{l}\text { Increased average } \\
\text { temperature }\end{array}$ & $\begin{array}{l}\text { - Increase in morbidity } \\
\text { and mortality } \\
\text { - Decreased air quality - } \\
\text { Increased respiratory } \\
\text { disease }\end{array}$ & $\begin{array}{l}\text { Capacity issues due to } \\
\text { increased admissions } \\
\text { infrastructure impact healthcare } \\
\text { worker heat stress water } \\
\text { availability energy availability }\end{array}$ & $\begin{array}{l}\text { High to } \\
\text { Extreme }\end{array}$ & $3-4$ \\
\hline
\end{tabular}




\begin{tabular}{|c|c|c|c|c|}
\hline & $\begin{array}{ll}\text { - } & \begin{array}{l}\text { Decreased water } \\
\text { quantity and quality }\end{array} \\
\text { - } & \begin{array}{l}\text { Decreased food } \\
\text { production - impacts } \\
\text { on diet }\end{array} \\
\text { - } & \text { Mental health } \\
\text { - } & \text { Heat stress } \\
\text { - } & \text { Water borne disease } \\
\text { - } & \text { Skin disease } \\
\text { - } & \text { Skin cancer }\end{array}$ & $\begin{array}{l}\text { - Infrastructure of hospital } \\
\text { coping with heat and health } \\
\text { care workers }\end{array}$ & & \\
\hline Extreme hot days & $\begin{array}{l}\text { - } \begin{array}{l}\text { Increase in morbidity } \\
\text { and mortality }\end{array} \\
\text { - } \quad \begin{array}{l}\text { Decreased air quality - } \\
\text { Increased respiratory } \\
\text { disease }\end{array} \\
\text { - } \quad \begin{array}{l}\text { Decreased water } \\
\text { quantity and quality }\end{array} \\
\text { - } \quad \begin{array}{l}\text { Decreased food } \\
\text { production - impacts } \\
\text { - }\end{array} \\
\text { - } \text { Mental health } \\
\text { - } \quad \text { Water stress } \\
\text { - } \quad \text { Skin disease } \\
\text { - Skin cancer }\end{array}$ & 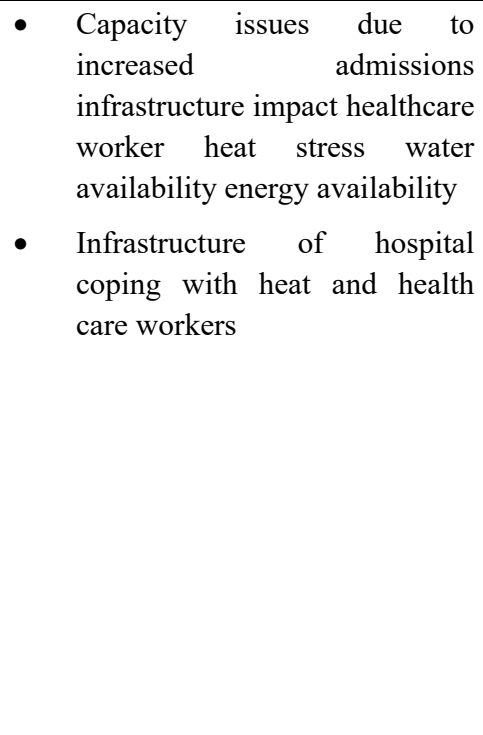 & Extreme & 5 \\
\hline $\begin{array}{l}\text { Flooding (inc. } \\
\text { landslides) }\end{array}$ & $\begin{array}{ll}\text { - } & \text { Death } \\
\text { - } & \text { Food security and } \\
\text { safety } \\
\text { - } \\
\text { - } \quad \text { Increased quality } \\
\text { disease } \\
\text { - } \quad \text { Increase in NCD } \\
\text { - } \quad \text { Skin diseases } \\
\text { - } \quad \text { Water borne disease } \\
\text { - } \quad \text { Sanitation issues e.g. } \\
\text { - } \text { pit latrines } \\
\text { - } \quad \text { Psychosocial issues }\end{array}$ & $\begin{array}{l}\text { - Increased pressure and access } \\
\text { to health services } \\
\text { - } \quad \text { Stress on human and resource } \\
\text { capacity } \\
\text { - } \begin{array}{l}\text { Health centres affected by food } \\
\text { security - quantity and quality }\end{array}\end{array}$ & $\begin{array}{l}\text { High to } \\
\text { Extreme }\end{array}$ & $3-4$ \\
\hline Drought & $\begin{array}{ll}\text { - } & \text { Food security and } \\
\text { nutrition } \\
\text { - } & \text { Water quality } \\
\text { - } & \text { Skin conditions } \\
\text { - } & \text { NCDs/mental health } \\
\text { - } & \text { Malnutrition } \\
\text { - } & \text { Air quality }\end{array}$ & 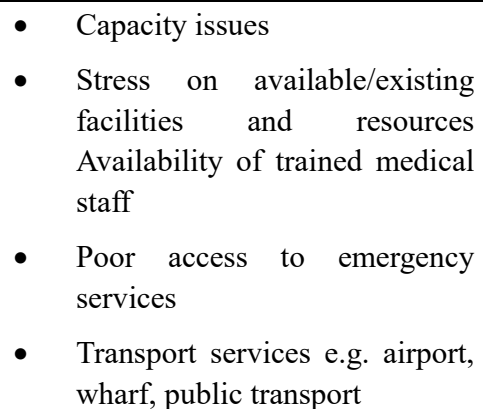 & $\begin{array}{l}\text { High to } \\
\text { Extreme }\end{array}$ & \\
\hline
\end{tabular}




\begin{tabular}{|c|c|c|c|c|}
\hline Wildfire & $\begin{array}{ll}\text { - } & \text { Injury } \\
\text { - } & \text { Air pollution - respiratory } \\
\text { impacts (asthma) } \\
\text { - } \quad \text { Food security }\end{array}$ & $\begin{array}{l}\text { - Destruction of health care } \\
\text { service, capacity issues }\end{array}$ & Extreme & $3-5$ \\
\hline Tsunami & - Death, injury & $\begin{array}{l}\text { - Access to hospital and } \\
\text { health care due to tsunami, } \\
\text { in Niuatopotapu only. } \\
\text { - Damage to houses, roads, } \\
\text { essential services }\end{array}$ & $\begin{array}{l}\text { High to } \\
\text { Extreme }\end{array}$ & 5 \\
\hline Earthquake & $\begin{array}{l}\text { - Increases in mental health } \\
\text { issues } \\
\text { - Loss of life } \\
\text { - Vulnerability to diseases e.g. } \\
\text { communicable diseases, } \\
\text { VBDs }\end{array}$ & - Access to health care & High & 5 \\
\hline $\begin{array}{l}\text { Volcanic activity, } \\
\text { includes related } \\
\text { earthquakes }\end{array}$ & $\begin{array}{ll}\text { - } & \text { Volcanic ash fall }- \text { pollutes } \\
\text { - } & \text { water, air } \\
\text { - } & \text { Water security } \\
\text { - } & \text { Community well-being } \\
\text { - } & \text { Mental health } \\
\text { - } & \text { Respiratory system issues } \\
\text { - } & \text { Increase } \\
\text { - } & \text { Malnutrition } \\
\text { - } & \text { Water borne disease } \\
\text { - } & \text { Loss of life/Injury } \\
\text { - } & \text { Mental health issues } \\
\text { - } & \text { Vommunicable diseases } \\
\text { e.g. dengue fever, Zika virus } \\
\text { etc. }\end{array}$ & $\begin{array}{l}\text { - Access to hospital and } \\
\text { health care due to volcanic } \\
\text { activity - Niuafo'ou } \\
\text { - Not enough medical } \\
\text { supplies, skills, capacity, } \\
\text { limitation }\end{array}$ & High & 5 \\
\hline $\begin{array}{l}\text { Volcanic activity } \\
\text { includes related } \\
\text { earthquakes }\end{array}$ & $\begin{array}{ll}\text { - } & \text { Volcanic ash fall - pollutes } \\
\text { - } & \text { Fater, air } \\
\text { - } & \text { Water security } \\
\text { - } & \text { Community well-being } \\
\text { - } & \text { Mental health } \\
\text { - } & \text { Respiratory system issues } \\
\text { - } & \text { Increase } \\
\text { - } & \text { non-communicable diseases } \\
\text { - } & \text { Water borne disease } \\
\text { - } & \text { Loss of life/Injury }\end{array}$ & $\begin{array}{l}\text { - access to hospital and health } \\
\text { care due to volcanic activity } \\
\text { - Tongatapu } \\
\text { - Not enough medical } \\
\text { supplies, skills, capacity, } \\
\text { limitation }\end{array}$ & Low & $\begin{array}{l}\text { No } \\
\text { rating }\end{array}$ \\
\hline
\end{tabular}


- Mental health issues

- Communicable diseases

- Vulnerable to other diseases

e.g. dengue fever, Zika virus

etc.

Table 2. Health and health system impacts of prioritized natural hazards: Tsunami

\begin{tabular}{|c|c|c|c|c|}
\hline Adaptation strategies (investments) & $\begin{array}{l}\begin{array}{l}\text { Rating of } \\
\text { adaptation } \\
\text { strategy }\end{array} \\
\text { A-Adequate } \\
\text { I- Inadequate } \\
\text { D - } \\
\text { Developing } \\
\mathrm{N}-\text { Not in } \\
\text { place }\end{array}$ & $\begin{array}{l}\text { What is our } \\
\text { capacity - In } \\
\text { general and } \\
\text { for } \\
\text { vulnerable } \\
\text { regions and } \\
\text { groups? }\end{array}$ & $\begin{array}{l}\text { How can we } \\
\text { improve } \\
\text { resilience? } \\
\text { (implementation, } \\
\text { upgrading, } \\
\text { mitigation) }\end{array}$ & $\begin{array}{l}\text { Sectors } \\
\text { involved } \\
\text { and/or } \\
\text { supporting } \\
\text { evidence } \\
\text { (including } \\
\text { champions, } \\
\text { Government) }\end{array}$ \\
\hline
\end{tabular}

\section{Legislative or Regulatory}

National tsunami plan

National emergency act -2007

Meteorology Act 2017

SOP for tsunami (MET)

Communication Act - 2000

Community Emergency Plan
A

\begin{tabular}{|c|c|c|c|c|}
\hline $\begin{array}{l}\text { Improve public awareness of risks of tsunami } \\
\text { Conduct regular tsunami drills }\end{array}$ & I & $\begin{array}{l}\text { There is } \\
\text { public } \\
\text { awareness, } \\
\text { information } \\
\text { and drills but } \\
\text { needs more. } \\
\text { Recruit } \\
\text { qualified } \\
\text { people to } \\
\text { manage and } \\
\text { coordinate } \\
\text { drills and } \\
\text { simulation } \\
\text { exercises }\end{array}$ & $\begin{array}{l}\text { Publish more } \\
\text { awareness } \\
\text { materials for } \\
\text { people in the } \\
\text { community }\end{array}$ & $\begin{array}{l}\text { NEMO } \\
\text { Meteorology } \\
\text { MEIDECC } \\
\text { All clusters }\end{array}$ \\
\hline \multirow{3}{*}{$\begin{array}{l}\text { 3. Technological or Engineering, Infrastructure } \\
\text { Development and Ecosystem Intervention }\end{array}$} & \multirow[b]{3}{*}{ I } & \multirow[b]{3}{*}{$\begin{array}{l}\text { Dissemination } \\
\text { system in } \\
\text { place but not } \\
\text { effective }\end{array}$} & $\begin{array}{l}\text { Install more } \\
\text { sirens for tsunami }\end{array}$ & \\
\hline & & & $\begin{array}{l}100 \% \quad \text { radio } \\
\text { coverage }\end{array}$ & $\begin{array}{l}\text { MEIDECC } \\
\text { TCC }\end{array}$ \\
\hline & & & $\begin{array}{l}\text { Uptime internet, } \\
\text { access } 100 \% \\
\text { Install automated } \\
\text { dissemination } \\
\text { system }\end{array}$ & $\begin{array}{l}\text { Digicel } \\
\text { Communication } \\
\text { Cluster }\end{array}$ \\
\hline
\end{tabular}

Integrate all Meteorology

relevant acts and MEIDECC

policies.

regulations in Incorporate

place

gender equality

into policies

Geology

Department

All clusters 


\section{Health Intervention and Health Systems}

D There is a

Endorse MoH Disaster Management Plan

disaster

management

$\mathrm{D}$

plan but needs

Establish Emergency Medical Team endorsement

Health plans

are not

Establish training programs for tsunami

incorporated

into some of

the response

Involve health workers in tsunami drills and simulation exercise.

and emergency

plans

$\begin{array}{lrl}\begin{array}{l}\text { Get } \\ \text { endorsed. }\end{array} & \text { DMP } & \text { MoH } \\ \text { Ensure } & \text { WHO } \\ \text { well-trained EMT } & \text { NEMO }\end{array}$

Incorporate health plan into all response plan

$\mathrm{N}$

5.

Research/Information/Surveillance/Monitoring

Improve health information management system

D

Systems in

Ensure Health

place but not

Information

(mprove health information management system

I

adequate and

needs

improvement

System

digitization

$\mathrm{MoH}$

Improve monitoring weather system

Install radars

Table 3. Health and health system impacts of prioritized natural hazards: Tropical Cyclone

\begin{tabular}{|c|c|c|c|c|}
\hline Adaptation strategies (investments) & $\begin{array}{l}\begin{array}{l}\text { Rating of } \\
\text { adaptatio } \\
\text { n strategy }\end{array} \\
\mathrm{A} \quad- \\
\text { Adequate } \\
\mathrm{I} \\
\text { Inadequate } \\
\mathrm{D} \\
\text { Developin } \\
\mathrm{g} \\
\mathrm{N}- \\
\text { place Not in }\end{array}$ & $\begin{array}{l}\text { What is our } \\
\text { capacity - In } \\
\text { general and } \\
\text { for } \\
\text { vulnerable } \\
\text { regions and } \\
\text { groups? }\end{array}$ & $\begin{array}{l}\text { How can we improve } \\
\text { resilience? } \\
\text { (implementation, } \\
\text { upgrading, } \\
\text { mitigation) }\end{array}$ & $\begin{array}{l}\text { Sectors } \\
\text { involved } \\
\text { and/or } \\
\text { supporting } \\
\text { evidence } \\
\text { (including } \\
\text { champions, } \\
\text { Government) }\end{array}$ \\
\hline
\end{tabular}

\section{Legislative or Regulatory}

Climate Change Policy

- Community Emergency Plans

- Communications Act 2000

Environment Management Act 2010

Regional TC Operating Plan

Tropical Cyclone Standard Plan (TCSP)

Follow up with other ministries to see if they have emergency policies in place.
Water

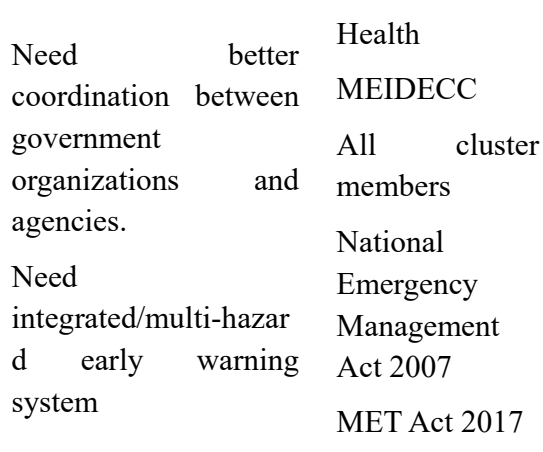




\section{Public Education \& Communication}

Awareness program

Awareness week (MEIDECC)

Improve school syllabus by including traditional

knowledge about weather and climate

D

MEIDECC

Public awareness to be more regular

Ministry of

Education

E.g. TV program, radio program, social media I

(Facebook), workshops and trainings

\section{Technological or Engineering, \\ Infrastructure Development and Ecosystem \\ Intervention}

Improve TC early warning system

Disseminating system for example sirens.

Improve internet access

Enhance emergency management e.g. training, volunteer

$\begin{array}{lll} & \text { Need more sirens } & \text { Army } \\ & \text { Uptime internet access } & \text { MOI } \\ \text { Some system } & 100 \% & \text { TPL } \\ \text { in place but } & \text { Need better radio } & \text { TCC/Digicel } \\ \text { need } & \text { All government } \\ \text { improvement } & \text { coverage. } & \begin{array}{l}\text { and } \\ \text { non-governmen } \\ \text { t organizations }\end{array} \\ & \begin{array}{l}\text { Uystem. } \\ \end{array} & \end{array}$

Improve storage for medical supplies

Identify the committee that can revise the Health Disaster Management Plan, request endorsement from CEO for Health

Some system in place but still need a lot of improvement $\mathrm{s}$

Identify focal points in every ward for emergency coordination.

Develop training programs on disaster management (ongoing training course)
Conduct trainings for healthcare workers on emergency management

\begin{tabular}{|c|c|c|c|c|}
\hline \multirow{3}{*}{\multicolumn{2}{|c|}{$\begin{array}{l}5 . \\
\text { Research/Information/Surveillance/Monitorin } \\
\text { g }\end{array}$}} & \multirow{2}{*}{\multicolumn{3}{|c|}{$\begin{array}{l}\text { Health } \\
\text { information }\end{array}$}} \\
\hline & & & & \\
\hline & & $\begin{array}{l}\text { system is } \\
\text { moving }\end{array}$ & & \\
\hline Improve health information management system & $\mathrm{D}$ & $\begin{array}{l}\text { towards } \\
\text { digitization. }\end{array}$ & & \\
\hline Improve monitoring weather system & I & $\begin{array}{l}\text { Monitoring } \\
\text { weather } \\
\text { system in } \\
\text { place but not } \\
\text { adequate. }\end{array}$ & Install radars & $\mathrm{MOH}$ \\
\hline
\end{tabular}


Table 4. Health and health system impacts of prioritized natural hazards: Flooding

\begin{tabular}{|c|c|c|c|c|}
\hline Adaptation strategies (investments) & $\begin{array}{l}\begin{array}{l}\text { Rating of } \\
\text { adaptation } \\
\text { strategy }\end{array} \\
\text { A - } \\
\text { Adequate } \\
\text { I } \\
\text { Inadequate } \\
\text { D } \\
\text { Developing } \\
\mathrm{N} \text { - Not in } \\
\text { place }\end{array}$ & $\begin{array}{l}\text { What is our } \\
\text { capacity - In } \\
\text { general and for } \\
\text { vulnerable } \\
\text { regions and } \\
\text { groups? }\end{array}$ & $\begin{array}{l}\text { How can we } \\
\text { improve } \\
\text { resilience? } \\
\text { (implementation, } \\
\text { upgrading, } \\
\text { mitigation) }\end{array}$ & $\begin{array}{l}\text { Sectors } \\
\text { involved } \\
\text { and/or } \\
\text { supporting } \\
\text { evidence } \\
\text { (including } \\
\text { champions, } \\
\text { Government) }\end{array}$ \\
\hline
\end{tabular}

1. Legislative or Regulatory

Enforcing current building codes (soon to be passed).

Not to build in certain areas, height of foundations
MIA/MoH

NEMO

$\mathrm{D}$

Red Cross

CBDRM

Need to consider impact of building up infrastructure e.g. roads on runoff and impact building houses up has on neighbors

Every village has an evacuation center and trained first aiders

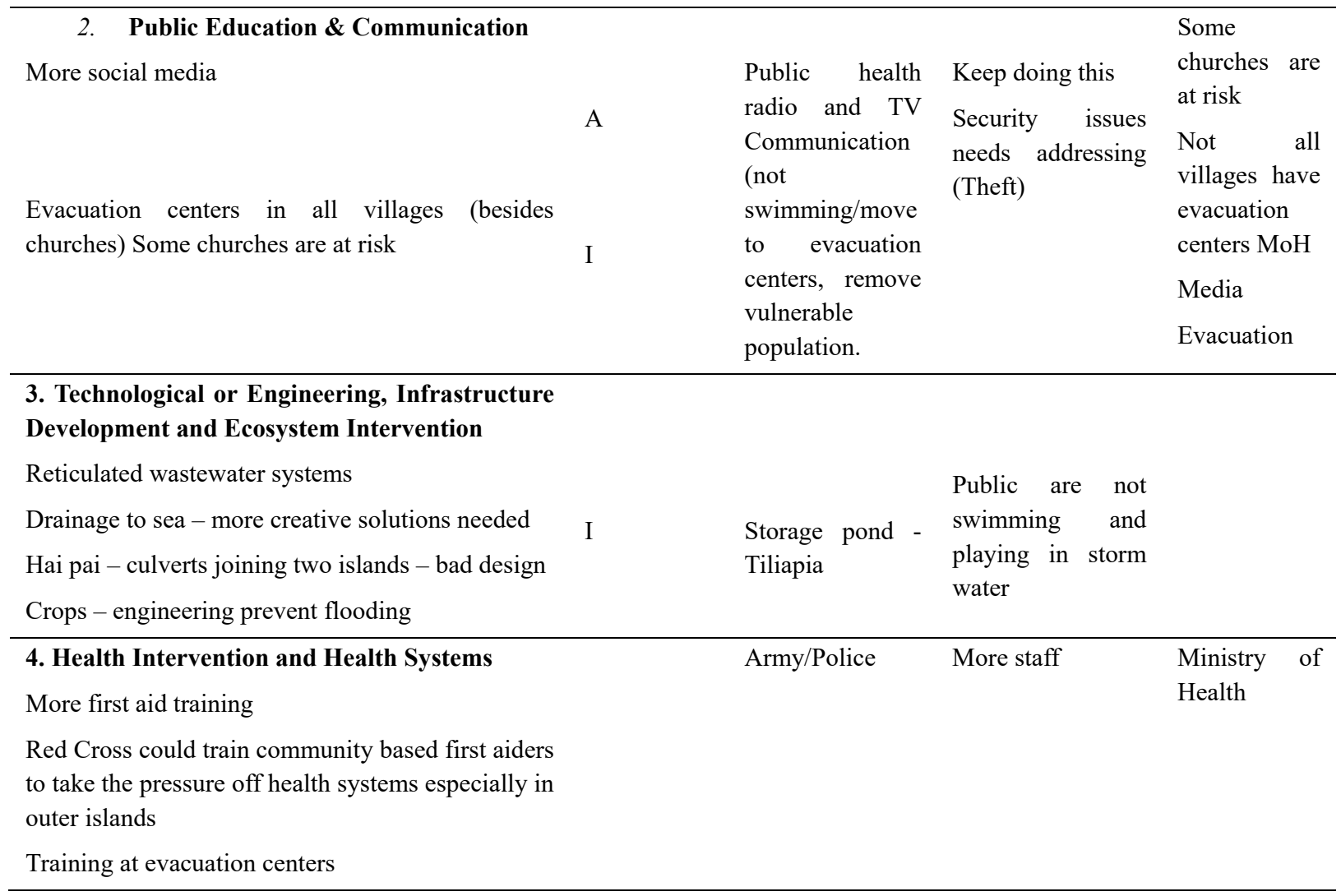


5.

Research/Information/Surveillance/Monitoring

Crops - research crops that can stand flooding

Drainage - find solutions

Tongan traditional medicines - their role/efficiency

Traditional knowledge

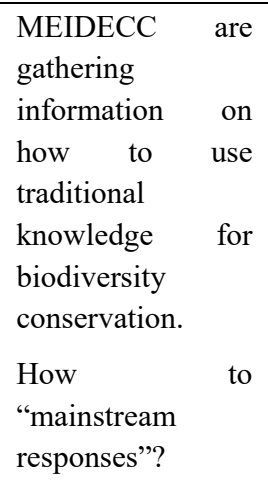

Table 5. Health and health system impacts of prioritized climate related (gradual): increases in temperature

\begin{tabular}{|c|c|c|c|c|}
\hline Adaptation strategies (investments) & $\begin{array}{l}\begin{array}{l}\text { Rating of } \\
\text { adaptation } \\
\text { strategy }\end{array} \\
\text { A - } \\
\text { Adequate } \\
\text { I } \\
\text { Inadequate } \\
\text { D } \\
\text { Developing } \\
\text { N - Not in } \\
\text { place }\end{array}$ & $\begin{array}{l}\text { What is our } \\
\text { capacity - In } \\
\text { general and } \\
\text { for } \\
\text { vulnerable } \\
\text { regions and } \\
\text { groups? }\end{array}$ & $\begin{array}{l}\text { How can we } \\
\text { improve } \\
\text { resilience? } \\
\text { (implementation, } \\
\text { upgrading, } \\
\text { mitigation) }\end{array}$ & $\begin{array}{l}\text { Sectors } \\
\text { involved } \\
\text { and/or } \\
\text { supporting } \\
\text { evidence } \\
\text { (including } \\
\text { champions, } \\
\text { Government) }\end{array}$ \\
\hline
\end{tabular}

\section{Legislative or Regulatory}

Regulating maximum temperatures for working, schools etc.

Triggers

Government

Air conditioning in government buildings

Building code - adequate ventilation

JNAP 2

Meteorological data predicting temperature increases

$\begin{array}{ll}\text { MIA } & \text { Radio for older } \\ \text { community } & \text { MIA } \\ \text { Climate } & \text { NGOs } \\ \text { change week } & \text { MEIDECC - } \\ 13^{\text {th Oct - }} & \text { EU GIZ } \\ \text { Disaster Day } & \text { Mangrove } \\ \text { Self-sufficient } & \text { planting } \\ \text { programs }- & \text { Coastal planting } \\ \text { Amataki Loa } & - \text { ridge to reef } \\ \text { (TCDT) people } \\ \text { Coconuts } \\ \begin{array}{l}\text { Early warning } \\ \text { system for Weather forecasts } \\ \text { tsunami }\end{array} & \begin{array}{l}\text { Communication } \\ \text { unique to each } \\ \text { and Information } \\ \text { country. }\end{array}\end{array}$

Early warning systems 
Radio/social media of daily forecasting

Security of water supplies
Careful that information is not too detailed.

Visual - easier to understand

EMT role and development of a team Training for food ready to vendors, health deploy in inspectors and deploy in storage in times of Health

\section{Health Intervention and Health Systems}

Improved training programmes and information on emergency management

(under development) heat, outbreaks.
5.

\section{Research/Information/Surveillance/Monitoring}

Linking health data (more presentations to health centers and hospitals) when high temperature events occur

Priorities water security in Outer Islands - Ha'apai

Strengthen rainwater collection on outer islands

$\begin{array}{lr}\begin{array}{l}\text { Child } \\ \text { climate }\end{array} & \text { change } \\ \text { programs } & (\mathrm{TCDT}) \\ \text { Working } & \text { in } \\ \text { schools } & \\ \text { MEIDECC } & - \\ \text { CRSP Climate } \\ \text { Resilient Sector } \\ \text { Project } \\ \text { Climate resilient } \\ \text { building } & - \text { Ha'apai } \\ \text { Hospital } & \\ \text { Tonga water board }\end{array}$

Table 6. Health and health system impacts of prioritized climate related (extreme): Cyclones

\begin{tabular}{|c|c|c|c|c|}
\hline \multirow{7}{*}{ Adaptation strategies (investments) } & $\begin{array}{l}\text { Rating of } \\
\text { adaptation } \\
\text { strategy }\end{array}$ & $\begin{array}{l}\text { What is our } \\
\text { capacity - }\end{array}$ & \multirow{7}{*}{$\begin{array}{l}\text { How can we } \\
\text { improve } \\
\text { resilience? } \\
\text { (implementatio } \\
\text { n, upgrading, } \\
\text { mitigation) }\end{array}$} & \multirow{7}{*}{$\begin{array}{l}\text { Sectors involved } \\
\text { and/or supporting } \\
\text { evidence } \\
\text { (including champions, } \\
\text { Government) }\end{array}$} \\
\hline & A - Adequate & In general & & \\
\hline & I $\quad-$ & and for & & \\
\hline & Inadequate & vulnerable & & \\
\hline & $\mathrm{D} \quad-$ & $\begin{array}{l}\text { regions and } \\
\text { grouns? }\end{array}$ & & \\
\hline & Developing & & & \\
\hline & $\begin{array}{l}\mathrm{N}-\text { Not in } \\
\text { place }\end{array}$ & & & \\
\hline
\end{tabular}

\section{Legislative or Regulatory}

Building code

Strengthen existing process to enforce/incorporate code in construction

Government should review building legislation to address community housing

Statistics on buildings destroyed (TC Gita Feb 2018). It is possible to review/amen d legislation
Review/amend legislation Enforce bill
Infrastructure (MOI)

Finance

Health 


\section{Public Education \& Communication}

Needs to be ongoing/sustainable

Strengthen network partnership with relevant sectors, groups e.g. NGOs, government

Fully integrate CCA and DRM (syllabus)
Systems are

in place but

need

strengthening

Public

awareness

(TV, radio,

Facebook)

School visits

Better

coordination

to avoid

duplication

HR sufficient

Technical

resources

(lacking)

Early

warning

systems

Telecom
Documentation

(Reports, clips, videos)

Meteorology

Upgrade existing

Education

NEMO

Conduct

community

training on

cyclone response

Climate

(MEIDECC)

Radio/TV

TCC

Telecom

NGOs - Private Sector

\section{Technological or Engineering, \\ Infrastructure Development and \\ Ecosystem Intervention}

More mangrove replant

Introduce mangrove protection bill
I

D
Technologica

1 system to

be

developed.

Ecosystem in

development.
Direct assistance

to most

vulnerable

communities e.g.

CCTF - Water

tanks

\section{MEIDECC}

MOI

MAFF

Lands and Survey

NGOs

\section{Health Intervention and Health Systems}

Public Health Act Increase budget allocation to public health division to meet needs of staff, relating to capacity training, ER training, resources

Capacity building (training and upskilling)

Climate proofing of health centers/facilities

Community involvement in best health practices

More

funding

We need
champions in
health and
MPs

Upskill service providers (health officers)

Increase budget/funding

Make services more accessible to locals.

Localize

Increased awareness (public) 
5.

Research/Information/Surveillance/Monit oring

There needs to be an "established system" to manage and control surveying across government. Clear procedures for all government sectors to adhere to avoid duplication; in accuracy data.

Data needs to be collected and managed I better, and also needs to be shared.

Information gaps need to be addressed.

$\begin{array}{lll} & & \text { Statistics } \\ & & \text { Health } \\ & & \text { NEMO } \\ \text { Research - } & & \text { MEIDECC } \\ \text { we have } & & \text { All sectors private and } \\ \text { 'local } & & \text { NGOs } \\ \text { expertise' to } & & \text { ESR } \\ \text { conduct } & \text { Establish a data } & \\ \text { research } & \text { system } & \text { All government } \\ \text { Data } & \text { Train staff in } & \text { sectors } \\ \text { collection, } & \text { data collection, } & \text { Public } \\ \text { storing, } & \text { analysis } & \text { Donors } \\ \text { management } & & \text { (Regional/Internationa } \\ \text { is weak. } & & 1 \text { ) } \\ & & \text { SPC }\end{array}$

Table 7. Health and health system impacts of prioritized climate related (extreme): Drought

\begin{tabular}{|c|c|c|c|c|}
\hline Adaptation strategies (investments) & $\begin{array}{l}\begin{array}{l}\text { Rating of } \\
\text { adaptation } \\
\text { strategy }\end{array} \\
\mathrm{A} \\
\text { Adequate - } \\
\text { I } \\
\text { Inadequate } \\
\text { D } \\
\text { Developing } \\
\mathrm{N}-\text { Not in } \\
\text { place }\end{array}$ & $\begin{array}{l}\text { What is our } \\
\text { capacity - In } \\
\text { general and for } \\
\text { vulnerable } \\
\text { regions and } \\
\text { groups? }\end{array}$ & $\begin{array}{l}\text { How can we improve } \\
\text { resilience? } \\
\text { (implementation, } \\
\text { upgrading, mitigation) }\end{array}$ & $\begin{array}{l}\text { Sectors } \\
\text { involved } \\
\text { and/or } \\
\text { supporting } \\
\text { evidence } \\
\text { (including } \\
\text { champions, } \\
\text { Government) }\end{array}$ \\
\hline
\end{tabular}

\section{Legislative or Regulatory}

We cannot decide on legislations as we do not know if drought is included - as it is a rare incident. If 'yes' then it needs to be circulated/shared with relevant ministries.
Strengthen research into drought to provide more reliable data.

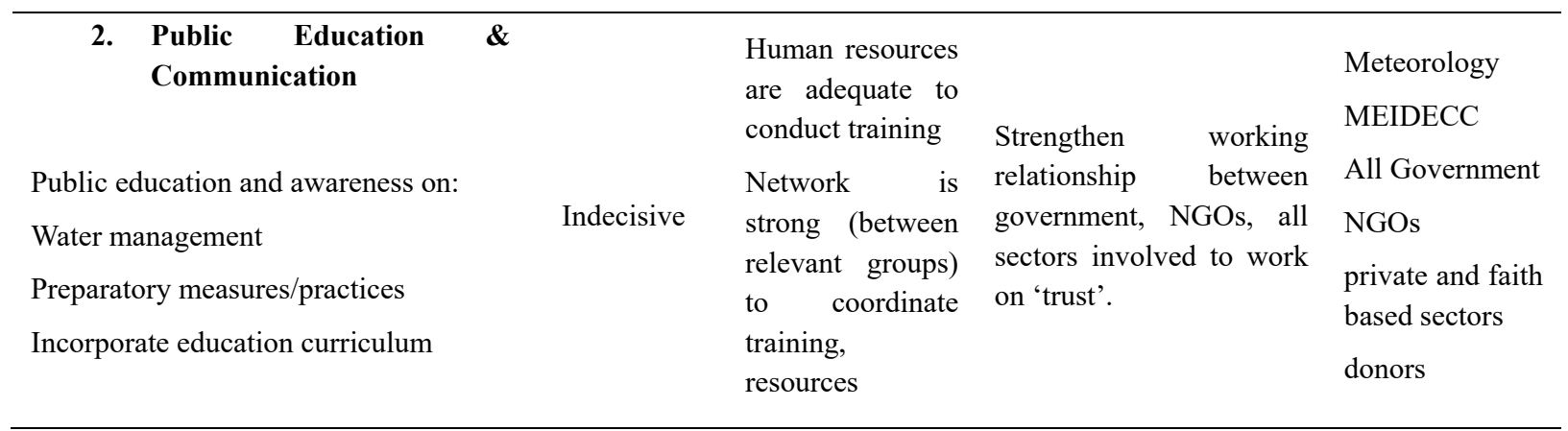




\section{Technological or Engineering, Infrastructure Development and Ecosystem Intervention}

WASTE Management Act 2016 Tree planting/mangroves

Review Waste Management Act and amend

Encourage recycle/reuse

$\begin{array}{lll} & \begin{array}{l}\text { Conduct } \\ \text { training on }\end{array} & \\ & \text { waste } & \text { Waste Authority } \\ \text { managemen } & \text { Health } \\ & \mathrm{t} \text { (household } & \text { MEIDECC } \\ & \text { level). } & \text { Environment } \\ \text { Review/enforc } & \text { Include } & \text { Tourism } \\ \text { e existing } & \begin{array}{l}\text { marine } \\ \text { pollution in }\end{array} & \text { MOI } \\ & \text { waste } & \text { NGOs } \\ & \text { managemen } & \\ & \mathrm{t} & \end{array}$

\section{Health Intervention and Health Systems}

Training on personal hygiene, water consumption, water management/storage

Health impacts on drought (counselling, mental health)

Local knowledge (utilize)

Build capacity (training and upskilling)

In some areas desalination of seawater may be an option (already some desalination plants on outer islands) in emergency situations there are smaller ones that can be shipped across but there have been issues finding a suitable vessel to transport this heavy equipment

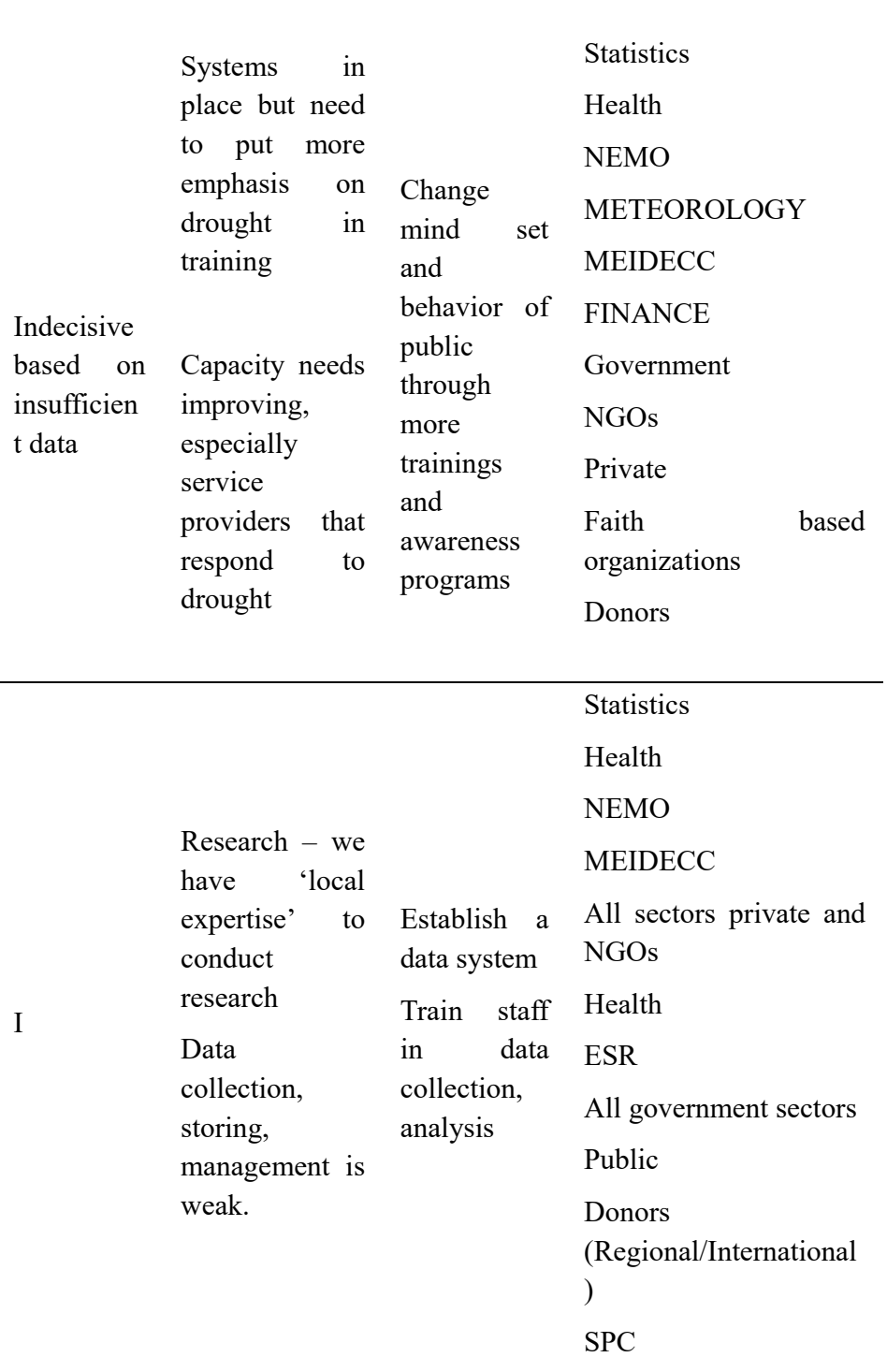

Systems in

place but need

to put more

emphasis on

drought

and
There needs to be an "established system" to I manage and control surveying across government

Clear procedures for all government sectors to adhere to avoid duplication; in accuracy data.

Resilient crops that cope in dry periods

I

\section{5. \\ 5.
Research/Information/Surveillance/Monitorin
g \\ g (1)}


Table 8. Adaptation strategies for each hazard by the level of priority (highest at the top)

\begin{tabular}{|c|c|c|c|c|c|c|}
\hline Hazard & Adaptation Option & $\begin{array}{l}\text { Hi } \\
\text { gh }\end{array}$ & $\begin{array}{l}\text { M } \\
\text { ed }\end{array}$ & $\begin{array}{l}\mathbf{L} \\
\mathbf{0} \\
\mathbf{w}\end{array}$ & $\begin{array}{l}\text { Ove } \\
\text { rall }\end{array}$ & $\begin{array}{l}\text { Weighte } \\
\text { d Total }\end{array}$ \\
\hline \multicolumn{7}{|l|}{ Cyclone/ } \\
\hline \multirow[t]{13}{*}{ Tsunami } & Endorse health disaster management plan & 3 & & & 3 & 9 \\
\hline & Improve monitoring weather system & 3 & & & 3 & 9 \\
\hline & Improve health information management system & 1 & 3 & & 4 & 9 \\
\hline & Mainstream other emergency policies and include surveying data & 2 & & & 2 & 6 \\
\hline & Strengthen enforcement of building code & 2 & & & 2 & 6 \\
\hline & Create emergency/medical management teams & 2 & & & 2 & 6 \\
\hline & Create/enhance emergency management training/capacity e.g. volunteers & 1 & 1 & & 2 & 5 \\
\hline & $\begin{array}{l}\text { Improve school syllabus including traditional knowledge and weather and } \\
\text { climate }\end{array}$ & 1 & & 1 & 2 & 4 \\
\hline & Training in emergency management for healthcare workers & & 1 & 1 & 2 & 3 \\
\hline & Renew building code especially community housing & & & 2 & 2 & 2 \\
\hline & $\begin{array}{l}\text { Increase public awareness (TV, radio, partnership with relevant networks, } \\
\text { social media) }\end{array}$ & & & 1 & 1 & 1 \\
\hline & More eco-system adaptation (mangroves) & & & & 0 & 0 \\
\hline & Avoid duplication & & & & 0 & 0 \\
\hline \multirow[t]{11}{*}{ Drought } & Resilient crops & 1 & 4 & 1 & 6 & 12 \\
\hline & $\begin{array}{l}\text { Training (personal hygiene, health impacts, water consumption, storage, } \\
\text { management) }\end{array}$ & 3 & 1 & & 4 & 11 \\
\hline & Research - Develop Government procedures for drought management & 3 & & 1 & 4 & 10 \\
\hline & Include more legislation for drought & 1 & 1 & 3 & 5 & 8 \\
\hline & Public education (water management, and curriculum) & 1 & 2 & 1 & 4 & 8 \\
\hline & New rain water storage tanks to have volume indicators & 2 & & 2 & 4 & 8 \\
\hline & Legislation of water tank size (minimum size) & 1 & 1 & & 2 & 5 \\
\hline & tree planting & 1 & & 1 & 2 & 4 \\
\hline & Encourage recycling/reuse & 1 & & & 1 & 3 \\
\hline & Review and amend waste management act & & 1 & & 1 & 2 \\
\hline & Use local knowledge & & & & 0 & 0 \\
\hline \multirow[t]{10}{*}{ Flooding } & Ensure every village has an evacuation center & 2 & 1 & 3 & 6 & 11 \\
\hline & Enforcing current building codes & 3 & & 1 & 4 & 10 \\
\hline & Improve food resilience (engineering, diverting, storage) & 3 & & 1 & 4 & 10 \\
\hline & Future-proof reticulated waste water systems & 3 & & & 3 & 9 \\
\hline & Increase first aid training & 1 & 3 & & 4 & 9 \\
\hline & Improve drainage to the sea e.g. culverts & 2 & 1 & & 3 & 8 \\
\hline & Restricting building or building foundation heights & 2 & & 1 & 3 & 7 \\
\hline & Crops research (able to withstand flood events) & 1 & 2 & & 3 & 7 \\
\hline & $\begin{array}{l}\text { Mainstream traditional knowledge systems e.g. Tongan medicine to } \\
\text { increase resilience/understanding weather patterns/birds/animals }\end{array}$ & 1 & 1 & & 2 & 5 \\
\hline & Create new opportunities (new crops, freshwater aquaculture) & & 1 & & 1 & 2 \\
\hline
\end{tabular}


Temperatur Adequate drinking water supply (plus maintenance and security), e increase especially on the outer islands

Linking health and climate data (e.g. hospital admissions)

Create more shade (e.g. coconuts and you can drink them)

Update building code - ventilation

$\begin{array}{lllll}2 & 6 & 1 & 9 & 19 \\ 4 & & & 4 & 12 \\ 1 & 3 & 1 & 5 & 10\end{array}$

Increased air conditioning in Government buildings (refuge in emergency)

Regulate/guidance on outdoor exposure (schools, walking)

Ecosystem based adaptation (all systems)

$\begin{array}{lll}3 & 3 & 3 \\ 1 & 1 & 1 \\ & 0 & 0\end{array}$

\section{Copyrights}

Copyright for this article is retained by the author(s), with first publication rights granted to the journal.

This is an open-access article distributed under the terms and conditions of the Creative Commons Attribution license (http://creativecommons.org/licenses/by/4.0/). 